\title{
Efeito do teor de tanino do sorgo sobre a fermentação ruminal e parâmetros nutricionais de ovinos
}

\section{SERGIO LUCIO SALOMON CABRAL FILHO}

Tese apresentada ao Centro de Energia Nuclear na Agricultura, da Universidade de São Paulo, como requisito para a obtenção do título de Doutor em Ciências, área de concentração: Energia Nuclear na Agricultura.

\section{PIRACICABA}

Estado de São Paulo - Brasil

Março - 2004 


\title{
Efeito do teor de tanino do sorgo sobre a fermentação ruminal e parâmetros nutricionais de ovinos
}

\section{SERGIO LUCIO SALOMON CABRAL FILHO}

\author{
Zootecnista
}

Orientador: Prof. Dr. ADIBE LUIZ ABDALLA

Tese apresentada ao Centro de Energia Nuclear na Agricultura, da Universidade de São Paulo, como requisito para a obtenção do título de Doutor em Ciências, área de concentração: Energia Nuclear na Agricultura.

PIRACICABA

Estado de São Paulo - Brasil

Março - 2004 


\section{Dedico,}

À minha mulher Vladia e às minhas filhas Bianca e Maiara 


\section{Agradeço}

- ao Centro de Energia Nuclear na Agricultura, por conceder-me a oportununidade de desenvolver meus estudos;

- à FAPESP pelo financiamento deste trabalho e pela concessão da bolsa de estudo;

- ao Dr. Adibe Luiz Abdalla, pela orientação dos trabalhos, pela confiança e amizade;

- à Dra. Dorinha M.S.S. Vitti Kennedy, pelo auxílio na orientação dos trabalhos e pela amizade;

- ao Dr. Ives Cláudio da Silva Bueno, pelo constante participação em todas as fases deste trabalho;

- ao Dr. José Avelino Santos Rodrigues, pelo grande auxílio na realização dos experimentos;

- ao Dr. Ciniro Costa, pelo apoio na realização dos experimentos e pelas oportunas sugestões;

- a Sra. Marília R. G. Henyei, pela revisão dos trabalhos e constante apoio bibliotecário;

- aos funcionários Sra. Maria Regina S. R. Peçanha, Sr. Lécio Aparecido Castilho e Sr. Joaquim Everaldo M. dos Santos, pelo constante apoio nas análises laboratoriais e nos experimentos;

- aos amigos Cibele Longo, Eduardo F. Nozella, Jonas A. R. Paschoal, Patricia B. Godoy, Patrizia A. Bricarello, Raquel S. Dias e Sarita P. Gobbo, pelo apoio nos trabalhos e pela grande amizade e dedicação.

- às empresas AGROMEN, EMBRAPA, PIOONER e SEMEALI pelo fornecimento das sementes e dos grãos de sorgo utilizados nos experimentos; 


\section{SUMÁRIO}

página

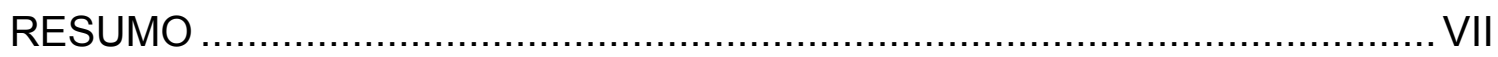

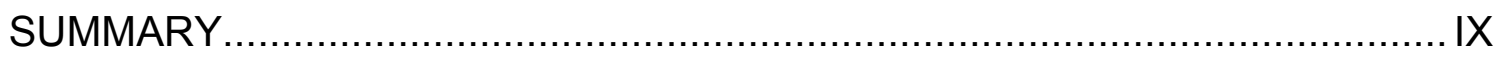

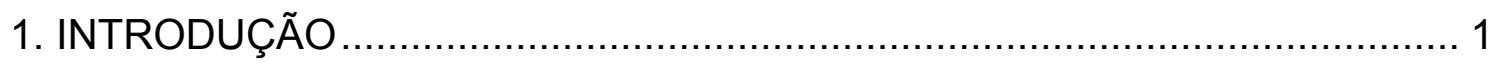

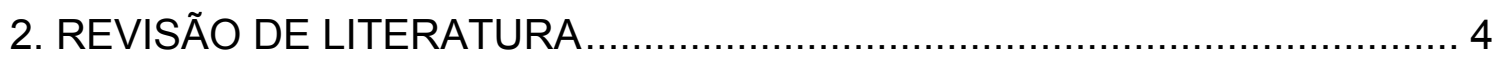

2.1. O sorgo na nutrição animal .............................................................. 4

2.2. Características químicas dos taninos ................................................ 7

2.3. Taninos na nutrição dos ruminantes ................................................. 11

2.4. Métodos para avaliações dos taninos ................................................ 14

2.4.1 Análise dos compostos fenólicos por colorimetria .............................. 14

2.4.2. Bioensaio através da metodologia in vitro da produção de gases .......... 15

3. AVALIAÇÃO DA FERMENTAÇÃO RUMINAL DE CULTIVARES DE SORGO ATRAVÉS DA TÉCNICA DE PRODUÇÃO DE GASES ................................. 16 
RESUMO

SUMMARY

3.1. Introdução . 18

3.2. Material e métodos. 20

3.2.1. Cultivares 20

3.2.2. Área experimental e parcelas 20

3.2.3. Preparo do solo e plantio . 21

3.2.4. Coleta e preparo das amostras 22

3.2.5. Análises bromatológicas e avaliações "in vitro" 22

3.2.6. Análise dos taninos 23

3.2.7. Análise dos dados 23

3.3. Resultados 24

3.4. Discussão. 40

3.5. Conclusões 44

4. EFEITO DO TANINO DO SORGO EM DIETAS COM ALTA PROPORÇÃO DE CONCENTRADO PARA OVINOS . 45

RESUMO 45

SUMMARY 46 


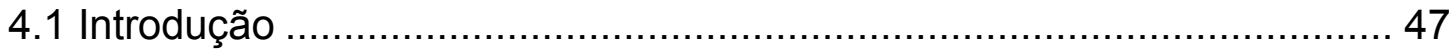

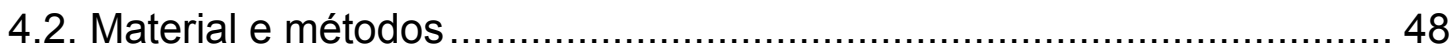

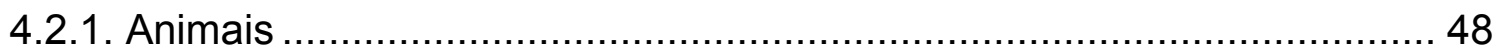

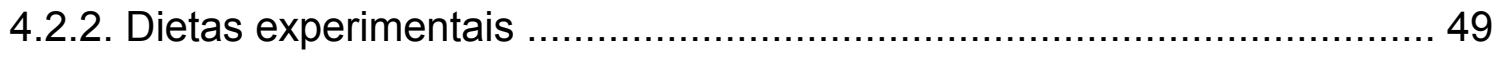

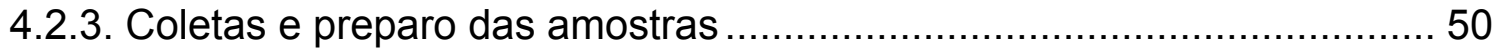

4.2.4. Digestibilidade in vivo e balanço de nitrogênio .................................... 50

4.2.5. Medidas da síntese microbiana .................................................... 51

4.2.6. Determinações do $\mathrm{pH}$ e nitrogênio amoniacal do rúmen ....................... 53

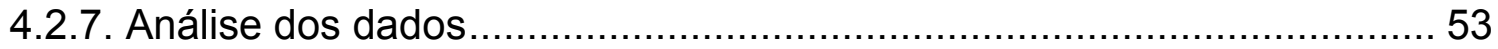

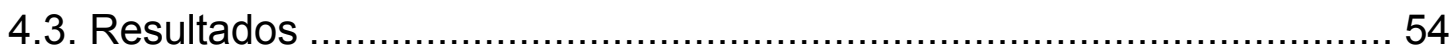

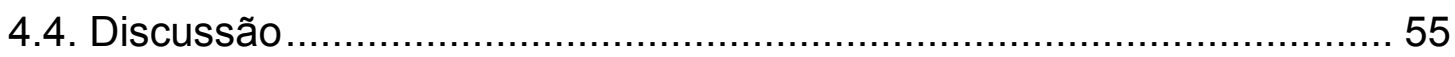

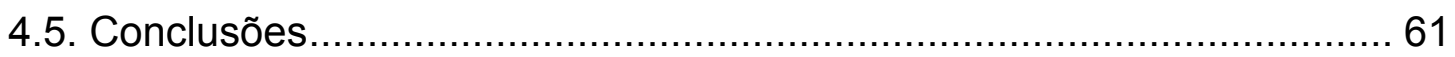

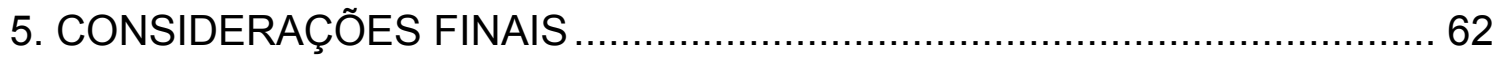

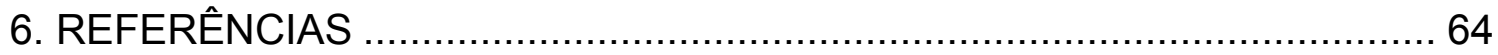




\title{
Efeito do teor de tanino do sorgo sobre a fermentação ruminal e os parâmetros nutricionais de ovinos
}

\author{
Autor: Sergio Lucio Salomon Cabral Filho \\ Orientador: Prof. Dr. Adibe Luiz Abdalla
}

\section{RESUMO}

O sorgo [Sorghum bicolor (L.) Moench] é um cereal de grande importância na nutrição animal, entretanto esta planta produz compostos secundários capazes de interferir na digestão dos animais. Entre esses, destacam-se os taninos condensados, macromoléculas capazes de formar ligações com outras moléculas como proteínas e carboidratos, resultando em um menor aproveitamento destes nutrientes pelos animais. $O$ objetivo deste trabalho foi avaliar os efeitos antinutricionais dos taninos do sorgo na nutrição dos ovinos. O estudo foi dividido em dois experimentos. O primeiro avaliou oito cultivares de sorgo de diferentes propósitos através da técnica in vitro de produção de gases. Foram medidos os parâmetros de fermentação e a degradabilidade da matéria seca. Os cultivares foram plantados em 4 blocos e colhidos em quatro idades: 30, 60, 90 e 120 dias após o plantio. Aos 120 dias foi realizada uma colheita dos grãos separadamente. Os efeitos antinutricionais do sorgo foram avaliados através da técnica de bioensaio medindo os incrementos na produção de gases pela adição do polietilenoglicol (PEG 6000). O segundo estudo avaliou os efeitos dos taninos presentes nos grãos de sorgo em dietas de ovinos com alta proporção de concentrado. Foram avaliadas três 
dietas, $\mathrm{C} 0, \mathrm{C} 1$ e $\mathrm{C} 2$; contendo $0 ; 1,9$ e 2,4 \% de taninos condensados respectivamente, formuladas a partir de três cultivares de sorgo. Foram utilizados seis ovinos machos adultos, com fístulas de rúmen e duodeno e peso médio de $56 \mathrm{~kg}$. Os animais foram mantidos em gaiolas de metabolismo em um delineamento de dois Quadrados Latinos 3x3 simultâneos, com três períodos e três tratamentos. Foram determinados o consumo voluntário, o balanço de nitrogênio e as digestibilidades aparentes da matéria seca (MS), da fibra em detergente neutro (FDN) e da proteína bruta (PB). As concentrações de nitrogênio microbiano (NM) foram determinadas utilizando o ${ }^{15} \mathrm{~N}$ como traçador. Os resultados obtidos no primeiro ensaio demonstraram o elevado valor nutricional da planta de sorgo, sendo que os cultivares graníferos e de duplo propósito promoveram uma maior fermentação microbiana nas idades de 60, 90 e 120 dias após o plantio. No segundo experimento, as dietas formuladas a partir dos cultivares com taninos ( $\mathrm{C} 1$ e C2) promoveram um menor balanço de nitrogênio, embora não tenham sido identificadas reduções nas concentrações de nitrogênio microbiano no duodeno. 


\title{
Effect of sorghum tannins on ruminal fermentation and sheep nutritional parameters
}

\author{
Author: Sergio Lucio Salomon Cabral Filho \\ Adviser: Prof. Dr. Adibe Luiz Abdalla
}

\section{SUMMARY}

Sorghum bicolor (L.) Moench is an important cereal crop used in animal nutrition. However, this plant produces secondary compounds, such as condensed tannin, which are able to interfere in the animal digestion. Condensed tannins are macromolecules that can bind to other molecules such as protein and carbohydrates reducing the fully utilization of nutrients by the animals. The aim of this work was to evaluate the anti-nutritional effects of tannins present in sorghum on sheep nutrition. This study was divided in two trials. In the first trial eight cultivars of sorghum with different purposes were evaluated through the in vitro gas production technique measuring the fermentation parameters and dry matter degradability. The cultivars were cultivated in four blocks and harvested at 30,60, 90 and 120 days post planting. Grains were collected at 120 days post-plant. The anti-nutritional effects of sorghum were evaluated through the bioassay technique by measuring increase in gas production due to addition of poly-ethylene-glycol (PEG 6000). The second trial evaluated the tannins effects using sorghum grain for sheep fed high concentrate diets. Three diets, C0, C1 and C2, containing 0, 1.9 and $2.4 \%$ condensed tannin, respectively, and formulated from three different sorghum 
cultivars were evaluated. Six male and adult sheep ( $\cong 56 \mathrm{~kg}$ ), fitted with ruminal and duodenal cannulaes, were kept in metabolic cage. This trial was designed in a double Latin Square $3 \times 3$ simultaneously, with 3 periods and 3 treatments. It was determined voluntary intake, nitrogen balance (NB) and dry matter, neutral detergent fiber and crude protein apparent digestibility. Concentrations of microbial nitrogen (MN) were determined through ${ }^{15} \mathrm{~N}$ tracer. Results in the first trial demonstrated high nutritional value of sorghum. Cultivars with grain purpose or with double purposes promoted higher microbial fermentation at 60,90 and 120 days post planting. In the second trial, the diets containing tannins ( $\mathrm{C} 1$ and C2) presented lower $\mathrm{NB}$ although decreasing in $\mathrm{MN}$ concentrations in the duodenum was not observed. 


\section{INTRODUÇÃO}

O sorgo [Sorghum bicolor (L.) Moench] é um dos cereais mais cultivados no mundo. A maior área plantada esta localizada nos continentes da África e da Ásia, onde o sorgo é a melhor opção de cultivo em regiões áridas e semi-áridas, sendo muito utilizado na alimentação humana.

Devido a sua grande capacidade de produção, o sorgo também é muito empregado na alimentação animal. Os grãos são uma importante fonte de energia em dietas de monogástricos e ruminantes, podendo substituir outros cereais como o milho e o trigo.

No Brasil, o sorgo ainda é pouco plantado. Segundo o IBGE, sua safra no ano de 2003 está estimada em 1.700 .000 toneladas e sua produção apresentou um aumento de $125 \%$ em relação a 2002 (www.ibge.gov.br). A produção de sorgo no Brasil é praticamente toda destinada à alimentação animal, sendo muito utilizado como um ingrediente substituto ao milho pelas indústrias de ração.

$\mathrm{Na}$ alimentação animal, o sorgo pode ser explorado de diversas formas. Além dos grãos, a planta pode ser oferecida na forma de silagem, rolão, verde ou ainda ser pastejada. Embora o milho ainda seja o cereal mais plantado e mais produtivo, algumas particularidades do sorgo, como a tolerância a solos pobres e a baixa umidade, vêm contribuindo para o aumento da área plantada e da sua utilização na produção animal.

O desempenho da cultura de sorgo faz com que esta seja, atualmente, a mais indicada para o plantio intercalado com outras culturas como a soja nas 
condições do cento-oeste do Brasil, criando a perspectiva de grande crescimento da área cultivada no país.

Uma das características da planta de sorgo é a presença de compostos fenólicos como os taninos condensados. Estas macromoléculas (5.000-20.000 Daltons) são resultantes do metabolismo secundário dos vegetais. Alguns híbridos comerciais de sorgo apresentam elevadas concentrações de taninos nos grãos, sendo indicados principalmente para regiões que sofrem com o ataque de pássaros e apresentam umidade relativa elevada durante o período de safra.

Os taninos vêm sendo bastante estudados nos grãos de sorgo, principalmente devido ao seu efeito negativo na digestão proteica de aves e suínos. Nos ruminantes, o efeito antinutricional é amenizado pela ação dos microrganismos do rúmen, porém alguns estudos têm demonstrado variações na retenção de nitrogênio, na absorção de aminoácidos e no consumo de matéria seca destes animais.

Embora em muitos casos os microrganismos são capazes de hidrolisar as moléculas de tanino, a capacidade de formar complexos com diferentes moléculas e a conhecida ação antimicrobiana, despertam o interesse para a realização de mais estudos sobre a ação destas moléculas no rúmen e seus efeitos na absorção de nutrientes pelos animais.

A caracterização nutricional da planta de sorgo e o estudo dos efeitos dos seus compostos secundários possibilitam um melhor emprego desta planta na alimentação animal assim como um melhor entendimento dos efeitos positivos e negativos destas moléculas na digestão dos ruminantes.

Os ovinos são pequenos ruminantes com grande potencial de produção no Brasil e o sorgo é um alimento importantíssimo na formulação de dietas para estes animais. O estudo das características digestivas da planta de sorgo pelos ovinos poderá trazer benefícios para a produção destes animais e contribuir no conhecimento sobre a fisiologia da digestão dos ruminantes. 
Este trabalho procurou estudar a fermentação ruminal de alguns cultivares de sorgo, assim como identificar os efeitos dos seus compostos secundários através de metodologias in vitro e in vivo.

Os resultados destes estudos são apresentados neste trabalho na forma de três capítulos. O primeiro capítulo revisa algumas características e importâncias do sorgo e dos taninos na nutrição dos ruminantes. No segundo, é apresentado um estudo da fermentação ruminal in vitro de diferentes cultivares de sorgo. E o terceiro apresenta os resultados de um ensaio in vivo com ovinos, que avaliou dietas contendo grãos de sorgo, formuladas a partir de três cultivares, com diferentes concentrações de taninos condensados. 


\section{REVISÃO DE LITERATURA}

\subsection{O sorgo na nutrição animal}

O crescente aumento das áreas plantadas com sorgo no Brasil mostra o potencial deste cereal na alimentação animal. A maior inclusão de grãos de sorgo na formulação de rações balanceadas pode ser explicada pelo aumento da oferta deste grão no mercado. A maior tolerância desta planta à seca reduz o risco do plantio no final do período chuvoso (safrinha), resultando na maior oferta do grão em períodos de entressafra do milho.

Da mesma maneira, a utilização do sorgo para a produção de silagem também vem crescendo a cada ano, principalmente nas regiões áridas e semiáridas, onde esta cultura se sobressai (Souza et al., 2003).

Zago (1991) demonstra a versatilidade da planta de sorgo na nutrição de ruminantes e acredita que esta planta poderá resolver o problema de estacionalidade de forragens. O mesmo autor destaca o sorgo como uma das culturas mais importantes para a produção de silagem, contribuindo com 10-12 $\%$ da área total cultivada com silagem no Brasil.

Os grãos de sorgo apresentam valores nutricionais muito próximos ao do trigo e do milho, com a composição média de $70 \%$ de carboidratos, $12 \%$ de proteína, $3 \%$ de gordura, $2 \%$ de fibra e 1,5\% de cinzas (Ruskin et al., 1996). Este autor encontrou variações de 8,3 a 15,3 \% nos teores de proteína entre cultivares dos Estados Unidos. 
O sorgo pode apresentar menores valores de digestibilidade da matéria orgânica quando comparado ao milho (Streeter et al., 1990b), provavelmente devido às características do amido e sua interação com a proteína.

Estes autores analisaram a composição química do milho e de quatro híbridos de sorgo e encontraram diferenças na proteína e no amido. O sorgo apresentou maior conteúdo de endosperma farináceo, com alta concentração de amido e baixa concentração de proteína.

Estudos de Okoh et al. (1982) investigaram o potencial de 16 cultivares da Nigéria na alimentação de aves e encontraram maiores teores de proteína comparados ao milho. Entretanto, concluíram que a eficiência na utilização desta proteína depende do balanço de aminoácidos e das concentrações de tanino das variedades.

Uma das características da planta de sorgo é a presença de compostos fenólicos resultantes do seu metabolismo secundário. Os principais compostos fenólicos presentes na planta de sorgo são os ácidos fenólicos, os flavonóides e os taninos (Hahn et al., 1984).

Os taninos condensados são classificados como fatores antinutricionais e podem limitar o desempenho animal (Rostango et al., 1973b; Elkin \& Rogler, 1991). Grãos com teores de taninos maiores do que $1 \%$ podem diminuir a digestibilidade de metionina, aminoácido limitante ao desenvolvimento de aves e suínos. Entretanto não acarreta problemas nutricionais para os ruminantes, com exceção dos bezerros, quando ainda não possuem rúmen funcional (Teixeira, 2001).

A exigência de grãos de sorgo para o mercado de aves e suínos fez com que as empresas de sementes desenvolvessem híbridos com baixo teor de tanino nos grãos. Para silagem ainda é bastante discutida a utilização de híbridos graníferos e forrageiros, principalmente devido a diferenças de produção de matéria seca por área (Nussio \& Manzano, 1999).

Normalmente os híbridos forrageiros possuem teores mais elevados de tanino, pois são originados de plantas mais rústicas. A seleção de variedades 
com maiores concentrações de taninos (grãos marrons) está associada com as perdas de produtividade devido ao ataque de pássaros, insetos, fungos etc. (Rodrigues, 1996; Nsahlai et al., 1998).

Segundo Bullard \& York (1986), a presença de taninos nos grãos de sorgo está relacionada com uma região da semente conhecida como testa (pericarpo). Os autores descrevem uma classificação de genótipos de sorgo baseada na extração de taninos, que classificam os genótipos como tipo I: cultivares que não contém a testa e conseqüentemente não apresentam tanino; tipo II: cultivares que apresentam testa e tanino, entretanto, não apresentam elevadas concentrações nos grãos maduros em extração com metanol; e o tipo III: cultivares que após o amadurecimento dos grãos apresentam elevadas concentrações de taninos extraíveis em metanol.

Atualmente no Brasil os híbridos de sorgo são classificados como: graníferos com alto tanino ou com baixo tanino e forrageiros.

Embora a presença de taninos no sorgo esteja mais relacionada com os grãos, alguns trabalhos que analisaram diferentes partes da planta (Nsahlai et al., 1998) identificaram a presença destes compostos na folha, bainha e caule. Neste trabalho, os autores também estudaram a seletividade dos ovinos e notaram uma a preferência dos animais por partes da planta com menores concentrações de tanino.

Diversos estudos (Leinmüller et al., 1991; Scalbert, 1991; McSweeney et al., 2001) demonstram a capacidade antimicrobiana dos taninos condensados, podendo resultar em efeitos negativos na digestão e absorção de nutrientes. 


\subsection{Características químicas dos taninos}

Taninos são definidos como compostos secundários, portanto não estão envolvidos em processos essenciais das plantas (respiração, transpiração, fotossíntese, etc.). O termo tanino é antigo e foi dado devido à capacidade destes compostos de se ligarem com proteínas presentes na pele dos animais, transformando-as em couro (curtimento ou "tanning").

A descrição química dos taninos não é recente; Haslam (1966) descreveu estes compostos como macromoléculas ou polifenóis de elevado peso molecular (200 a 3.000 Daltons) capazes de formar ligações com vários tipos de proteínas, polissacarídeos e aminoácidos.

A capacidade de ligação destas moléculas depende da natureza dos taninos (moléculas grandes, mobilidade e baixa solubilidade) e das características químicas das moléculas a serem precipitadas (ponto isoelétrico, quantidades de prolina, etc.). As principais formas de ligações são as hidrofóbicas, pontes de hidrogênio, iônicas e covalentes (Cannas, 1999).

Os taninos são classificados em dois grupos principais, os taninos condensados e os taninos hidrolisáveis (Haslam, 1981). Os taninos hidrolisáveis são definidos como poliésteres de ácidos fenólicos (por exemplo, o ácido gálico e o ácido elágico), apresentam uma molécula de D-glucose na sua estrutura e não são muito abundantes na natureza. Os taninos condensados podem ser genericamente definidos como polímeros de moléculas de flavan-3-ols, unidas através de ligações carbono-carbono (Müeller-Harvey \& McAllan, 1992).

O grupo flavonol (Figura 1) é a unidade básica dos taninos condensados, apresentando monômeros conhecidos como catequinas ligados nas posições 2 e 3 do anel $C$. Os flavóis apresentam três radicais ou grupos substitutos $\left(R_{1}, R_{2}\right.$ e $\mathrm{R}_{3}$ ). Estes grupos podem ser $\mathrm{H}$ ou $\mathrm{OH}$ e estão diretamente relacionados com a atividade da molécula e com a capacidade de formar ligações com outras moléculas (Schofield et al., 2001). 


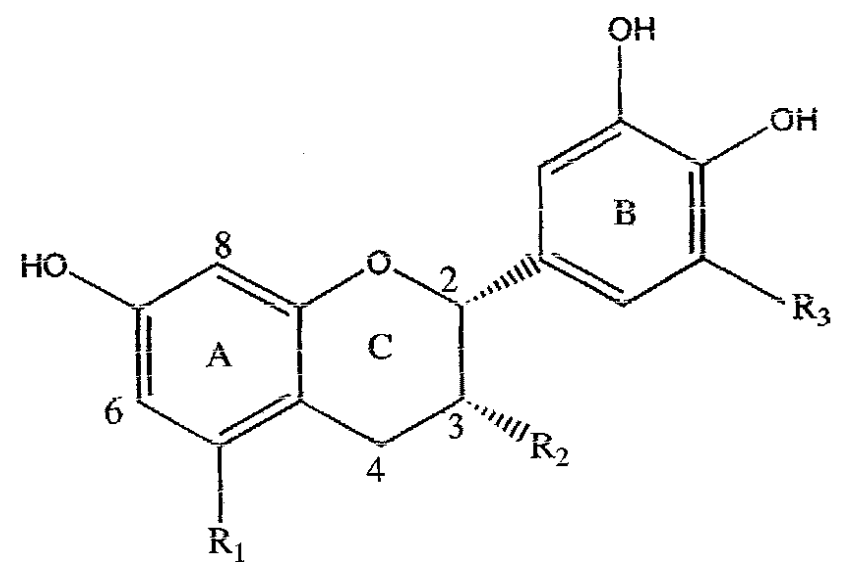

Figura 1 - Unidade básica dos taninos condensados (Schofield et al., 2001).

Os compostos fenólicos são sintetizados a partir da eritrose-4-fosfato, do fosfoenol piruvato e da acetil co-enzima A. As principais vias metabólicas para formação destes compostos nas plantas são a via do ácido shiquímico e a do acetato (Getachew, 1999).

Os taninos encontrados nos grãos de sorgo são classificados como oligocatequinas. Müeller-Harvey \& McAllan (1992) citam o trabalho de Gujer e colaboradores, que isolaram um novo grupo de flavan-flavanona glicosilado da

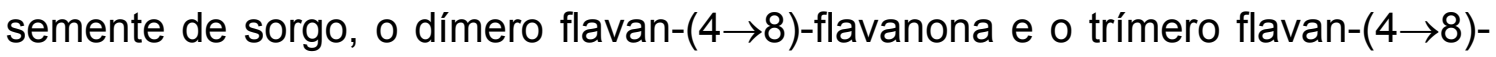
flavan-(4 $\rightarrow 8)$-flavanona (Figura 2).

As sementes de sorgo maduras podem apresentar teores de taninos condensados ou proantocianidinas maiores que $5 \%$ do seu peso. Estas são formadas por várias extensões de epicatequinas com um elevado grau de polimerização (8-9). Estes graus de polimerização são explicados por Butler (1982) e tendem a aumentar de acordo com a maturidade das sementes. 


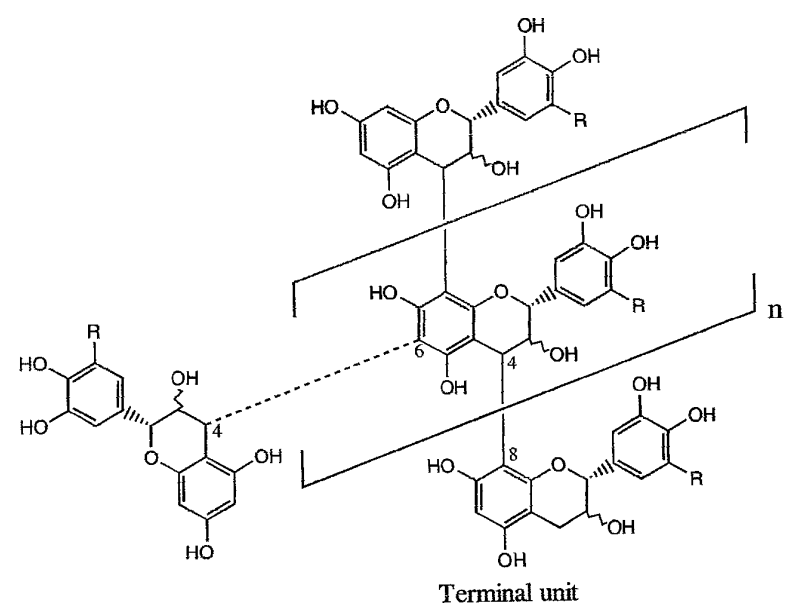

Figura 2. Taninos condensados (Schofield et al., 2001).

Nas plantas, os taninos estão localizados em vacúolos celulares nas folhas e na testa das sementes (Figura 3). As principais enzimas envolvidas na sua síntese e armazenamento são a chalcone sintetase (CHS), chalcone isomerase $(\mathrm{CHI})$, flavonóide-3'-hidroxilase $\left(\mathrm{F} 3^{\prime} \mathrm{H}\right)$, flavanona-3-hidroxilase $(\mathrm{F} 3 \mathrm{H})$, dihidroflavanol redutase (DFR), leucoantocianidina redutase (LAR), antocianidina sintetase (ANS), favanol-UDP-glicosil transferase (FGT), glutationa trans-membrana (GHS), enzimas de condensação (CE), inter-vacular flavan-3,4-diol (LC) e flavan-3-ol transportadora (C) (Aerts et al., 1999). 


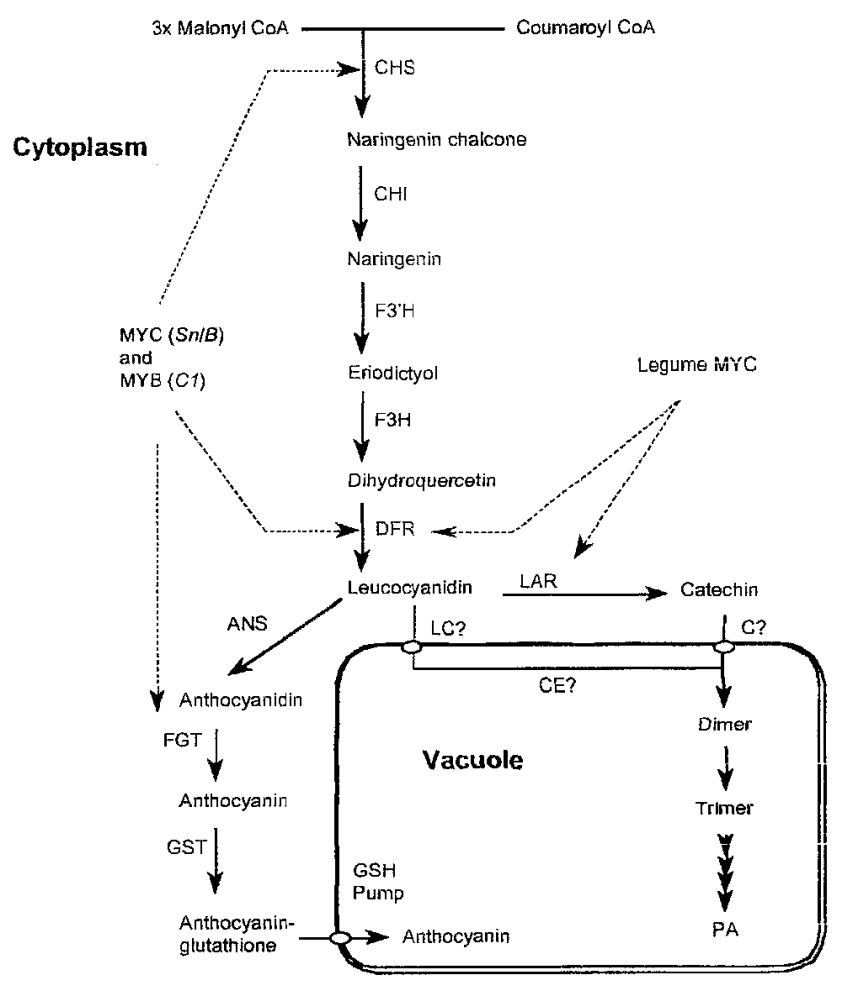

Figura 3. Localização dos taninos condensados na célula vegetal, transporte e armazenamento destes compostos nos vacúolos (Aerts et al., 1999).

Ainda não estão bem entendidos os motivos que fazem com que as plantas sintetizem e armazenem os compostos secundários. A princípio acredita-se na existência de um sistema de defesa dos vegetais contra o ataque de herbívoros e fungos.

Uma segunda teoria possível (Brandford \& Hsiao, 1982) baseia-se no princípio de que, em relação à presença de algum fator limitante ao desenvolvimento das plantas, as taxas de crescimento das plantas são mais sensíveis do que as taxas de fotossíntese. Portanto quando a planta é submetida a algum fator que limite seu crescimento, ela pode sintetizar estes 
compostos secundários como uma forma de armazenar os produtos da fotossíntese.

Esta teoria poderia explicar o motivo que leva as plantas a produzirem maiores quantidades de taninos quando se encontram em condições de baixa disponibilidade de nutrientes.

\subsection{Taninos na nutrição dos ruminantes}

Os taninos são classificados na nutrição animal como um fator antinutricional. Esta característica é mais notada em animais monogástricos, nos quais níveis maiores que $1 \%$ de taninos condensados na dieta podem trazer prejuízos para produção, afetando principalmente o consumo, a digestibilidade da proteína e dos aminoácidos essenciais (McDonald et al., 1995).

Pode-se dizer que os ruminantes são mais tolerantes aos taninos pois a ação dos microrganismos do rúmen diminui os efeitos negativos destes compostos. Normalmente os microrganismos do rúmen são capazes de detoxificar diversos fatores antinutricionais em compostos mais simples e não tóxicos (Selinger et al., 1996).

Os compostos fenólicos glicosilados como os flavonóides são metabolizados no rúmen através de hidrólise ácida ou enzimática do glicosídeo e posterior quebra do anel aromático. Os produtos da degradação dos falvonóides incluem acetato, butirato, di e monohidróxifenólicos e floroglucinol (McSweeney et al., 2001).

Taninos condensados são mais difíceis de serem degradados que os hidrolisáveis, podendo ser tóxicos para uma variedade de microrganismos. Isto pode explicar o efeito destas moléculas em retardar a biodegradação e diminuir a decomposição da matéria orgânica (Bhat et al., 1998). 
Os principais mecanismos de toxidez dos taninos descritos por Scalbert (1991) são a inibição enzimática, a privação do substrato, a ação direta na membrana e a privação de íons metálicos.

Segundo McSweeney et al. (2001), a despolimerização dos taninos condensados através da quebra das ligações C-C ainda não foi bem demonstrada em condições anaeróbicas e podem não ocorrer no rúmen.

Incapazes de serem degradados pelos microrganismos do rúmen, os taninos podem formar complexos com as proteínas dietéticas ou com as proteínas da mucosa digestiva, aumentando as perdas de proteína endógena (McNeill et al., 1998).

Quando a ingestão de taninos pelos ruminantes é muita elevada e excedem a capacidade de degradação dos microrganismos, a absorção de compostos fenólicos pode levar o animal a toxidez. Embora este processo ainda não esteja bem entendido, parece estar relacionado com o aparecimento de necroses do fígado e dos rins, foto-sensibilização e até a morte.

Os principais efeitos negativos encontrados por Lenmüller et al. (1991) em estudos in vitro foram no metabolismo dos carboidratos (diminuição dos ácidos graxos voláteis, da digestibilidade da matéria orgânica e da produção de gases) e no metabolismo das proteínas (redução dos conteúdos de amônia, inibição de atividade da urease, inibição da proteólise da caseína).

Já os efeitos in vivo mais citados na literatura são a diminuição na digestibilidade da proteína e da fibra, o menor aproveitamento do nitrogênio, a diminuição do consumo voluntário e dos indicadores de produção (diminuições na produção de leite e lã, no crescimento e no ganho de peso).

A diminuição do consumo voluntário está relacionada com a formação de complexos entre taninos e glicoproteínas da boca (adistringência). A diminuição da digestibilidade também pode ser responsável pelo efeito negativo no consumo (Cannas, 1999).

Aerts et al. (1999) estudaram diferentes experimentos da Nova Zelândia com ovinos consumindo forragens com concentrações variáveis de taninos 
condensados (Lotus corniculatus: 2-5 \%; Lotus peduncularus: 6-10 \% e Acacia aneura: 12 \%). Aumentos na absorção intestinal de aminoácidos (metionina e cistina), na produção de lã, nas taxas de ovulação, na produção de leite e nas quantidades de proteína no leite, foram observados quando os animais consumiam forragens com 4 a $6 \%$ de taninos condensados. A redução do consumo, da digestibilidade e da absorção do nitrogênio e de aminoácidos, assim como, da digestão da fibra e da produção de lã foram observadas para concentrações de 8 a 10 \% em rações com Lotus pendiculatus.

Outros estudos conduzidos com ovinos alimentados com Lotus spp confirmaram que concentrações de taninos condensados entre 2 e $5 \%$ aumentam a absorção aparente de aminoácidos essenciais pelo intestino (Waghorn, 1990).

Os taninos condensados se encontram na forma livre quando consumido pelos animais, formando complexos com as proteínas durante a ingestão, ruminação ou ao se misturarando com elas no rúmen. Estes complexos podem permanecer intactos durante todo o processo digestivo, indo sair nas fezes e representando uma importante perda de proteína dos alimentos (McNeill et al., 1998).

Os maiores benefícios dos taninos condensados na nutrição animal são a proteção das proteínas da degradação ruminal, o aumento da tolerância dos animais às helmintoses e à prevenção do timpanismo (Getachew, 1999).

Tanto os efeitos benéficos como os antinutricionais dos taninos condensados estão ligados à capacidade desta molécula em formar complexos com outras moléculas orgânicas.

O poder de adaptação e aproveitamento destas propriedades pelos ruminantes faz com que os taninos condensados sejam utilizados como uma ferramenta para tornar os sistemas de produção mais sustentáveis. 


\subsection{Métodos para avaliações dos taninos}

As metodologias utilizadas para a avaliação química dos taninos, classificadas por Makkar (2000) como convencionais, podem ser divididas em dois grupos: métodos químicos e métodos de precipitação das proteínas.

O autor acima considera como métodos químicos as determinações colorimétricas dos fenóis totais, dos taninos totais (utilizando o polivinilpolipirrolidona - PVPP) e dos taninos condensados e as determinações dos galotaninos através da cromatografia líquida de alta precisão (HPLC). E como métodos de precipitação a difusão radial, a precipitação com albumina sérica bovina e o método do papel de filtro com o corante Ponceau S.

\subsubsection{Análise dos compostos fenólicos por colorimetria}

A metodologia baseia-se na oxidação do analito fenólico e na redução do reagente com formação de um cromóforo. O método possibilita distinguir os taninos (fenóis que precipitam proteínas) dos fenóis que não são taninos.

Para diferenciar os taninos dos outros fenóis o método indicado foi descrito por Makkar et al. (1993) e utiliza uma matriz sólida, polivinilpolipirrolidona (PVPP). Este método assume que os fenóis que se ligam às proteínas são os mesmos que se ligam ao PVPP. A diferença entre os valores de fenóis totais antes e após a adição do PVPP vai indicar as concentrações de taninos.

Para análise dos taninos condensados, a metodologia do butanol-ácido (ou butanol-HCl) é atualmente a mais utilizada. A reação é baseada na despolimerização oxidativa catalizada por ácido das moléculas de taninos condensados, resultando na formação de moléculas de antocianidina vermelha, capazes de serem identificadas no fotocolorímetro (Schofield et al., 2001).

Segundo Makkar (2001), o método butanol-HCl foi proposto em 1973 por Bate-Smith e pode ser considerado mais específico para taninos condensados 
que a metodologia da vanilina, tradicionalmente utilizada na análise de taninos em sorgo e outros cereais.

\subsubsection{Bioensaio através da metodologia in vitro da produção de gases}

A técnica in vitro da produção de gases vem sendo utilizada ara avaliações de alimentos em relação à fermentação ruminal. $O$ equipamento utilizado é o semi-automático, desenvolvido na Universidade de Reading (Inglaterra) e descrita por Maurício et al. (1999). Alguns autores utilizaram esta metodologia com a adição de agentes ligantes de taninos (principalmente o polietileno glicol - PEG) para avaliar os efeitos do tanino nos processo digestivo dos ruminantes (Makkar et al, 1995; Getachew et al., 2000).

O aumento na produção de gases ou na degradabilidade com a adição de agentes capazes de se ligarem aos taninos, podem ser usados como índices dos efeitos dos taninos na degradação ruminal (Silanikove et al., 2001). Estes autores consideram como vantagens da metodologia a simplicidade do sistema e a diminuição dos efeitos causados pela insolubilidade dos taninos, embora classifiquem as informações como qualitativas (informam pouco sobre os efeitos in vivo). 


\section{AVALIAÇÃO DA FERMENTAÇÃO RUMINAL DE CULTIVARES DE SORGO ATRAVÉS DA TÉCNICA DE PRODUÇÃO DE GASES}

\section{RESUMO}

O sorgo vem sendo cada vez mais empregado na nutrição de ruminantes. Entretanto, ainda são limitadas as informações sobre a fermentação desta planta pelos microrganismos do rúmen. Os taninos condensados são compostos fenólicos presentes na planta do sorgo e são capazes de formarem ligações com alguns nutrientes da planta, podendo inibir a fermentação ruminal. $O$ objetivo deste trabalho foi estudar os aspectos fermentativos e a digestibilidade de oito cultivares de sorgo em diferentes idades e avaliar a presença e os possíveis efeitos dos taninos condensados utilizando a técnica do bioensaio. Oito cultivares de sorgo (graníferos e forrageiros) foram plantados em um delineamento de Blocos Casualizados em parcelas de $5 \times 4,5 \mathrm{~m}$. As plantas foram cortadas rente ao solo, em diferentes idades (30, 60, 90 e 120 dias) e os grãos colhidos após 120 dias. As amostras foram analisadas quanto aos conteúdos de matéria seca (MS), matéria mineral (MM), fibra em detergente ácido (FDA) e proteína bruta (PB). Após cada coleta foram realizados ensaios de produção de gases com e sem a adição do PEG (polietilenoglicol) e analisados os teores de taninos condensados (TC). Os cultivares apresentaram diferenças nutricionais $(P<0,05)$ a partir de 60 dias. Nesta fase os cultivares graníferos apresentaram os melhores resultados. As maiores degradabilidades da MS em $96 \mathrm{~h}$ (D96h) foram obtidas aos 30 dias e não houveram diferenças entre os cultivares $(P>0,05)$. Os cultivares graníferos 
mostraram os melhores resultados de D96h aos 60, 90 e 120 dias. Os grãos apresentaram as maiores médias de D96h para os cultivares sem taninos $(P<0,05)$. O bioensaio demonstrou incrementos da produção de gases na presença do PEG para os cortes e para os grãos. Estas diferenças foram correlacionadas com os TC apenas para os grãos $(P<0,05)$, pois as análises químicas não indicaram a presença de TC nos primeiros cortes. As características fermentativas da planta de sorgo demostraram o seu elevado valor nutricional, sendo que os cultivares graníferos e de duplo propósito promoveram um maior crescimento microbiano nas fases de 60, 90 e 120 dias. A técnica do bioensaio apresentou resultados compatíveis com as análises químicas apenas para os grãos, mostrando a necessidade de um maior número de ensaios em sistema semi-automático e as possíveis interações entre o PEG e outros compostos fenólicos.

\section{EVALUATION OF RUMINAL FERMENTATION OF SORGHUM TYPES THROUGH GAS PRODUCTION TECHNIQUE}

\section{SUMMARY}

Sorghum has been used as ruminant feed, however there are limited information about its rumen microbial fermentation. Condensed tannins (CT) are phenolic compounds present in sorghum and they are able to link to plant nutrients resulting in negative effects for rumen fermentation. The objectives of this work were to study the fermentation and degradability of sorghum cultivars at different ages and to measure CT effect using bioassay technique. Eight sorghum cultivars (grain and forage purpose) were planted in $5 \times 4.5 \mathrm{~m}$ plots in a randomized block design. Plants stovers were harvested at different ages (30, 60,90 and 120 day post sowing) and grain at 120 day. Samples were analyzed for dry matter (DM), mineral matter (MM), acid detergent fiber (ADF) and crude 
protein (CP). Samples were submitted to gas production determinations with and without poly-ethylene-glycol (PEG) addition and CT analysis. Nutritional differences $(P<0.05)$ were observed among cultivars after 60 days and grain purpose cultivars have better results. High 96 h DM degradability was obtained at 30 days samplings, but there were no significant differences among cultivars $(P>0,05)$. Best results for degradability at $96 \mathrm{~h}$ were obtained for grain purpose cultivars for 60, 90 e 120 days. Grains presented high degradability in cultivars without tannins $(P<0,05)$. In bioassay, sorghum plant and grains showed increased with PEG added. Correlations with those increases and CT content were significant only for grains $(P<0,05)$. Chemical analyses have not indicated presence of CT at first ages. Fermentative characteristics of sorghum plant demonstrated the excellent nutritional values of those plants. Grain purpose cultivars indicated high microbial growth at 60,90 and 120 days. Bioassay technique demonstrated compatible results with chemical analysis only for sorghum grains, suggesting new trials with semi-automated system and studies about PEG and others sorghum fenolics interactions.

\subsection{Introdução}

A utilização do sorgo [Sorghum bicolor (L.) Moench] na produção animal vem crescendo rapidamente no Brasil. Algumas características desta planta, como elevada produção de matéria seca, crescimento rápido e tolerância à seca (Ruskin et al., 1996), fazem com que o cultivo do sorgo apresente menor risco e possibilite maior produtividade de silagem em alguns sistemas de produção. Ultimamente o sorgo também vem sendo empregado em sistemas intensivos de pastejo pois sua elevada produtividade permite o uso de maiores taxas de lotação. 
Devido ao crescimento na utilização de cultivares de sorgo, algumas pesquisas foram realizadas com o objetivo de investigar as características nutricionais e as melhores formas de utilização destes cultivares na nutrição de ruminantes (Zago, 1999; Campos et al. 2003; Souza et al., 2003).

Grande parte destes estudos analisou a silagem de sorgo, por ser a forma mais utilizada nos programas de alimentação. Pouca informação ainda se tem sobre as características nutricionais da planta verde e do grão.

As metodologias in vitro não são capazes de estimar todos os aspectos da digestibilidade in vivo (Willians, 2000). Algumas possibilitam a determinação da degradabilidade potencial (Tilley \& Terry, 1963) e outras a degradabilidade potencial e as taxas de degradação (in situ e produção de gases). Devido às facilidades laboratoriais, ao menor tempo de execução e às dificuldades na manutenção dos animais, as metodologias in situ e in vitro vêm sendo muito utilizadas em estudos de digestibilidade.

Entre as metodologias in vitro, a produção de gases parece ser a mais prática, além disso, fornece informações das taxas de fermentação e possibilita estimar a produção de ácidos graxos voláteis e o consumo (Getachew, 1998).

Apesar do sorgo ser uma planta com excelente potencial para a nutrição animal, alguns cultivares podem apresentar maiores concentrações de compostos fenólicos como os ácidos fenólicos, os flavonóides e os taninos (Hahn et al., 1984).

Entre estes compostos secundários, os TC são os mais importantes para os ruminantes. Ainda existem muitas dúvidas em relação aos efeitos positivos e negativos dessas moléculas (McNeill et al., 1998; Aerts et al. 1999; Cannas, 1999).

Os efeitos negativos na fermentação ruminal podem ser estudados através da técnica in vitro de produção de gases, pois estes efeitos são refletidos no volume de gases produzidos. Os resultados deste tipo de estudo podem ser mais eficientes do que a análise química destes compostos, pois estas se baseiam em padrões que podem apresentar efeitos biológicos 
diferentes dos fatores antinutricionais presente nos alimentos (Getachew et al., 1998).

O bioensaio, metodologia desenvolvida por Makkar et al., (1995a), tem como base a o uso do polietileno-glicol (PEG 6.000) na determinação dos efeitos dos taninos condensados na produção de gases in vitro. $A$ afinidade das moléculas de tanino pelo PEG resulta em acréscimos na produção de gases e, através destas diferenças, é possível avaliar o efeito dos taninos presentes em um determinado alimento.

O objetivo deste trabalho foi estudar os aspectos fermentativos e a digestibilidade de oito cultivares de sorgo em diferentes idades e avaliar a presença e os possíveis efeitos dos taninos condensados na fermentação ruminal in vitro através da técnica do bioensaio.

\subsection{Material e métodos}

\subsubsection{Cultivares}

Para este estudo foram utilizados oito híbridos de sorgo: BRS305 e BRS306 (granífero-EMBRAPA); BR700 e BR701 (forrageiro-EMBRAPA); Saara (granífero-Agroceres/Monsanto); 8419 e 8118 (granífero-Pionner); 8050 (granífero-Agromen).

\subsection{2. Área experimental e parcelas}

O sorgo foi cultivado em uma área da Fazenda Experimental Areão da Escola Superior de Agricultura "Luiz de Queiroz" (ESALQ) da Universidade de São Paulo (USP) em Piracicaba, SP. A área de $1.000 \mathrm{~m}^{2}$ foi dividida em quatro blocos com oito parcelas, sendo cada parcela cultivada com uma variedade. Considerou-se como parcela experimental uma área de $5 \mathrm{~m}$ de comprimento e 
4,5 $\mathrm{m}$ de largura, onde foram plantadas 5 linhas espaçadas de 0,90 m. As duas linhas externas foram consideradas bordaduras (Figura 4).

\subsubsection{Preparo do solo e plantio}

A área foi arada, gradeada e o $\mathrm{pH}$ do solo corrigido aplicando-se $2 \mathrm{Mg}$ ha $^{-1}$ de calcário dolomítico 30 dias antes do plantio. A adubação com fósforo e potássio foi feita no plantio, com a aplicação de $200 \mathrm{~kg} \mathrm{ha}^{-1}$ da fórmula 00-2020 , com base nos resultados da análise do solo. O nitrogênio e o restante do potássio foram aplicados em cobertura $\left(100 \mathrm{~g} \mathrm{~m}^{-1}\right.$ linear de 30-00-10 com sulfato de amônia) aos 30 e 60 dias após o plantio. O enxofre foi aplicado na forma de sulfato de amônio, presente na fórmula utilizada para cobertura.

Bloco 1
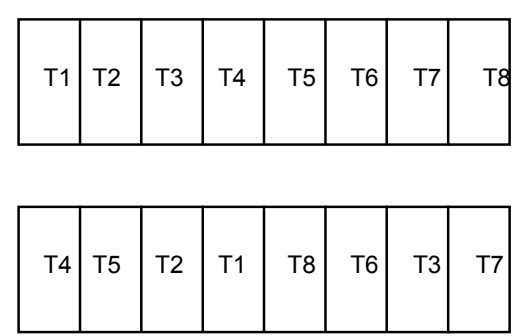

Bloco 2

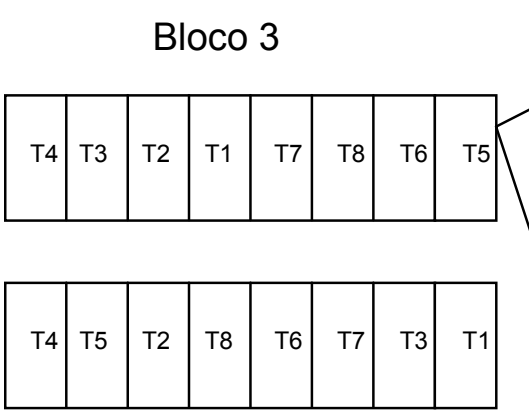

Bloco 4

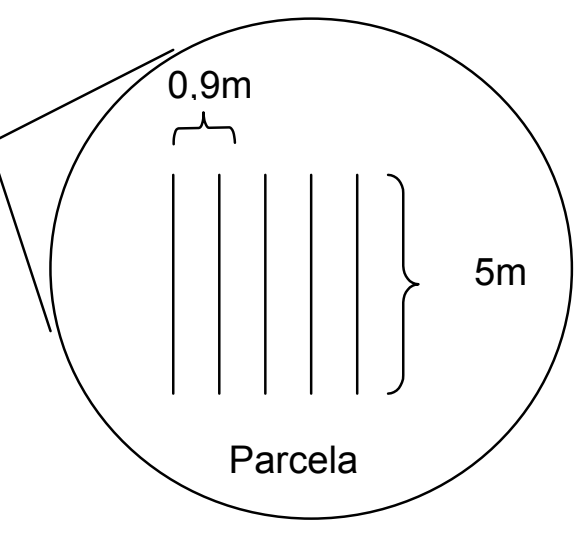

Figura 4. Croqui da área experimental (T1-BR701, T2-8118, T3-BR306, T4Saara, T5-8050, T6-BR700, T7-BRS305 e T8-8419). 


\subsubsection{Coleta e preparo das amostras}

As plantas foram colhidas em quatro diferentes estágios de desenvolvimento: 30, 60, 90 e 120 dias após o plantio. Foram feitos cortes da planta inteira e uma coleta apenas dos grãos aos 120 dias. Após a colheita, as plantas foram trituradas $(8-10 \mathrm{~mm})$, secas em estufa $\left(40-50^{\circ} \mathrm{C}\right)$, moídas $(1 \mathrm{~mm})$ e armazenadas em recipientes hermeticamente fechados. Os grãos foram colhidos nas panículas e processados seguindo os mesmos procedimentos descritos para as plantas inteiras. Estas amostras foram armazenadas a temperatura de $5-10^{\circ} \mathrm{C}$.

\subsubsection{Análises bromatológicas e avaliações "in vitro"}

Todas as amostras foram submetidas às determinações de MS, MM, PB e FDA segundo a A.O.A.C. (1990) e VAN SOEST et al. (1991).

As avaliações in vitro foram realizadas através do ensaio de produção de gases em sistema semi-automático (Mauricio et al, 1999). Foram desenvolvidos cinco ensaios (30,60, 90, 120 dias e grãos) para avaliar a fermentação ruminal dos cultivares e os possíveis efeitos do tanino na atividade microbiana.

O líquido ruminal (inóculo) foi coletado de ovinos fistulados no rúmen e alimentados à pasto com a suplementação de $500 \mathrm{~g} \mathrm{dia}^{-1}$ de um concentrado a base de milho, farelo de soja, uréia e melaço. $O$ inóculo foi incubado com $1 \mathrm{~g}$ de amostra na ausência e na presença de $1 \mathrm{~g}$ de polietileno glicol (PEG 6000) conforme Makkar et al. (1995) e Getachew et al. (2000). Foram utilizadas quatro garrafas para cada amostra, entre as quais o PEG foi adicionado em duas.

A pressão dos gases produzidos foi medida em diferentes intervalos de tempo até $96 \mathrm{~h}$ de incubação. Ao final da incubação o conteúdo das garrafas foi filtrado em cadinhos porimizados para determinação da degradabilidade ruminal da matéria seca. Os parâmetros da produção de gases foram ajustados pelo modelo de France et al. (1993). 


\subsubsection{Análise dos taninos}

As amostras foram analisadas quanto aos TC seguindo os procedimentos laboratoriais sugeridos por Makkar (2000). As amostras (200 $\mathrm{mg}$ ) foram submetidas à extração através da adição de uma solução de acetona $70 \%$ (10 ml) e levadas ao ultra-som por um tempo de 20 minutos. Em seguida os extratos foram centrifugados a $1900 \mathrm{rpm}$ a $4^{\circ} \mathrm{C}$ durante 10 minutos. Os taninos condensados foram analisados através do método do Butanol- $\mathrm{HCl}$ descrito por Porter et al. (1986), com base na despolimerização oxidativa dos taninos condensados, catalisada por ácido, resultando em antocianidina.

Alíquotas de $250 \mu \mathrm{l}$ dos extratos (diluídos com solução de acetona $70 \%$ quando necessário) foram colocadas em duplicata em tubos de ensaio com a adição de $50 \mu \mathrm{l}$ de $\mathrm{FeNH}_{4} \mathrm{SO}_{4}$ e $1500 \mu \mathrm{l}$ de butanol-HCl. Estes tubos foram aquecidos em banho-maria por $1 \mathrm{~h}$ a $95^{\circ} \mathrm{C}$, resfriados a temperatura ambiente e encaminhados para leitura em espectrofotômetro (Perkin Elmer EZ-150) a 550 $\mathrm{nm}$. Tubos brancos foram preparados de maneira semelhante, porém não aquecidos. Os valores das leituras dos tubos brancos foram descontadas dos valores obtidos das leituras das amostras.

\subsubsection{Análise dos dados}

Para os bioensaios foram utilizados os dados de produção total de gases (acumulado) em 24, 48 e 96h de fermentação, da degradabilidade in vitro e dos parâmetros gerados pelo modelo de France et al. (1993):

$$
\mathrm{V}=\mathrm{V}_{\mathrm{f}} \times\left\{1-\mathrm{e}^{\left[-\mathrm{b} \times\left(\mathrm{t}-\mathrm{t}_{0}\right)-\mathrm{c} \times\left(\sqrt{\mathrm{t}}-\sqrt{\mathrm{t}_{0}}\right)\right]}\right\}
$$


onde $\mathrm{V}=$ volume acumulado de gases, $\mathrm{V}_{\mathrm{f}}=$ volume potencial, $\mathrm{a}$ e $\mathrm{b}=$ constantes do modelo e $t_{0}=$ tempo estimado para que os microrganismos do rúmen iniciem a colonização do alimento ou fase lag ou lag time.

Todos os dados foram analisados através software estatístico SAS (2000). As análises dos dados dos bioensaios foram feitas através do modelo de blocos casualizados: $\mathbf{Y}_{\mathrm{ij}}=\boldsymbol{\mu}+\mathbf{t}_{\mathbf{i}}+\mathbf{b}_{\mathbf{j}}+\mathbf{e}_{\mathrm{ij}}$ e as comparações entre as médias através do teste de Tukey com $5 \%$ de probabilidade. A partir destas análises foi possível descrever o perfil fermentativo dos diferentes cultivares estudados e comparar as taxas de fermentação e os diferentes tratamentos (nas diferentes fases de desenvolvimento).

\subsection{Resultados}

A caracterização nutricional dos oito cultivares nas diferentes fases de desenvolvimento estão representadas nas figuras 5,6 e 7 . Não foram encontradas diferenças significativas $(P>0,05)$ entre a matéria seca (MS), a matéria mineral (MM), a fibra em detergente ácido (FDA) e a proteína bruta (PB) dos cultivares aos 30 dias de idade com médias superiores de 139, 374 e $162 \mathrm{~g}$ $\mathrm{kg}^{-1}$ para MS, MM, FDA e PB respectivamente. Aos 60 e 90 dias foram encontradas diferenças significativas $(P<0,05)$ entre os teores de MM e FDA.

Os maiores valores de MM (87 $\left.\mathrm{g} \mathrm{kg}^{-1}\right)$ foram encontrados para o BR306 e os menores $\left(68 \mathrm{~g} \mathrm{~kg}^{-1}\right.$ ) para o 8419-Pionner, aos 60 dias. Nesta mesma idade, o BR700 e o BR306 apresentaram os maiores valores de FDA (469 e $460 \mathrm{~g} \mathrm{~kg}^{-1}$ ), enquanto que o 8050-Agromen e o Saara-Monsanto os menores $\left(419\right.$ e $\left.415 \mathrm{~g} \mathrm{~kg}^{-1}\right)$. 
Com 90 dias, o cultivar 8050-Agromen apresentou a maior concentração de MM (63 g kg-1) e seu valor de FDA ficou entre os menores, junto com o BRS305 e o Saara-Monsanto $(349,349$ e 348 g kg-1, respectivamente).

Para o corte com 120 dias foram encontradas diferenças significativas apenas para a MM e para a FDA. O cultivar 8118-Piooner apresentou o maior valor de MM (71 $\left.\mathrm{g} \mathrm{kg}^{-1}\right)$, enquando que para FDA, o valor mais baixo obtido foi de $33 \mathrm{~g} \mathrm{~kg}^{-1}$ ), para o 8050-Agromen.

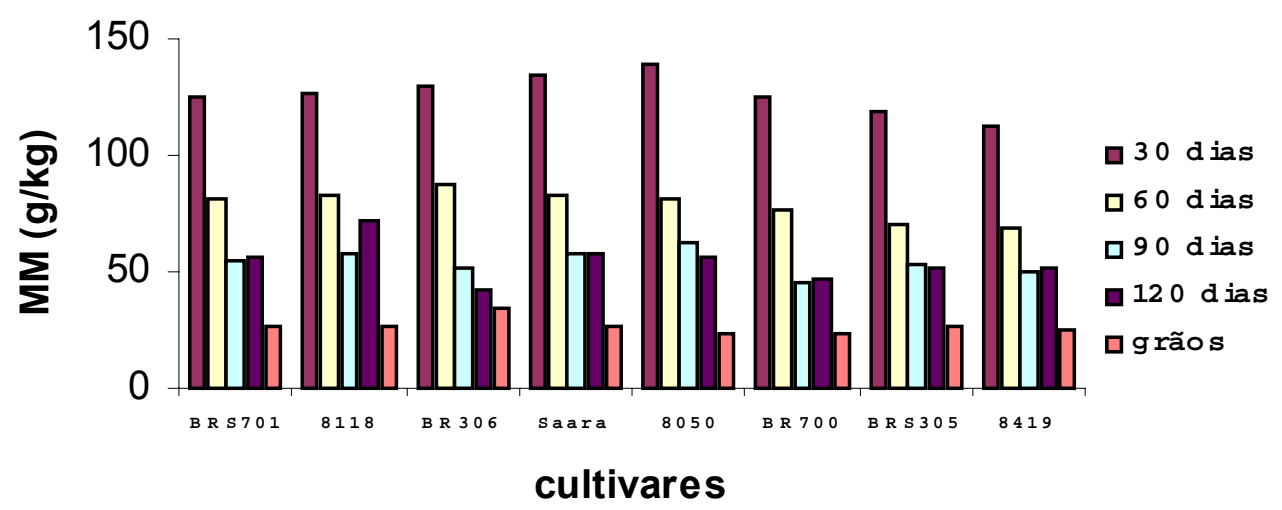

Figura 5. Concentração da matéria mineral de oito cultivares de sorgo em diferentes idades de desenvolvimento . 


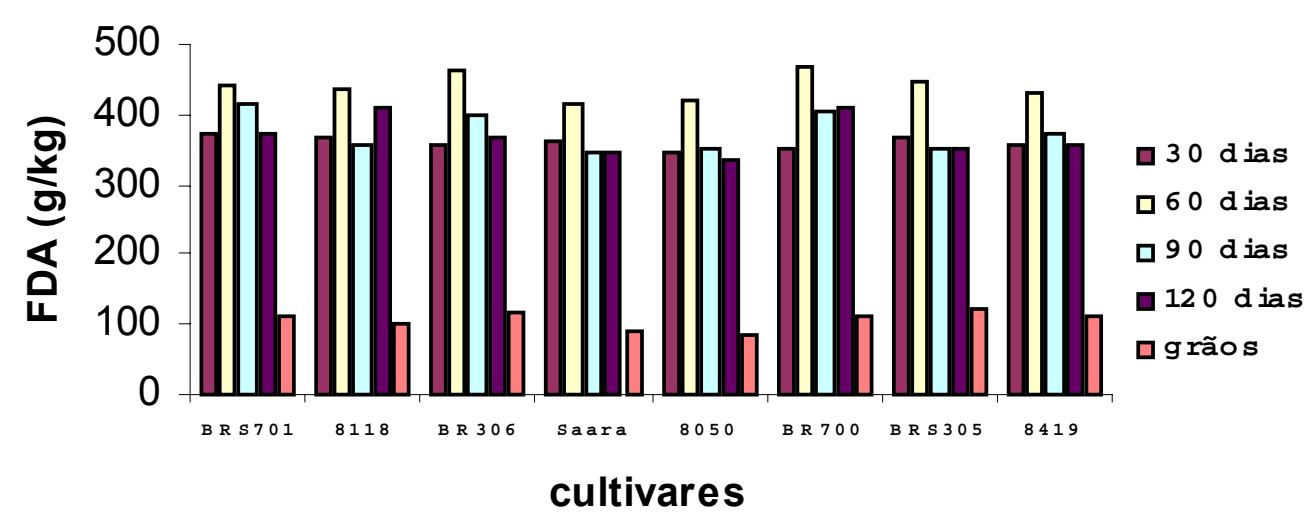

Figura 6. Concentração de fibra em detergente ácido de oito cultivares de sorgo em diferentes idades de desenvolvimento

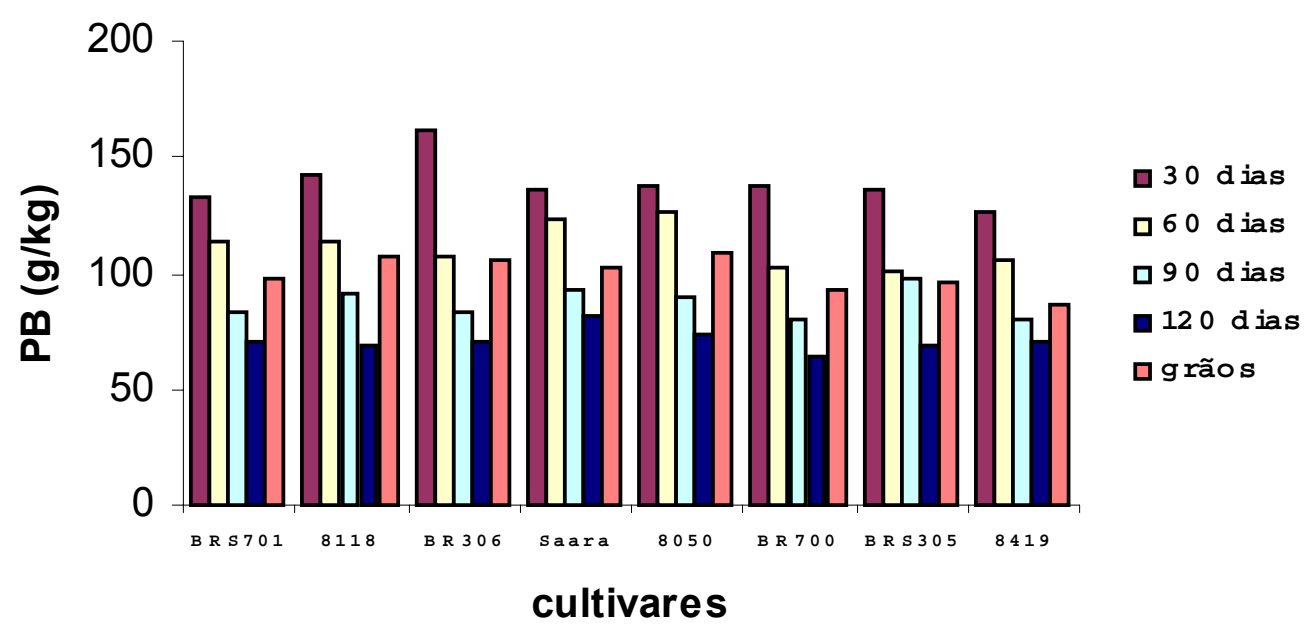

Figura 7. Concentração de proteína bruta de oito cultivares de sorgo em diferentes idades de desenvolvimento 
Em relação aos grãos foram encontradas diferenças significativas $(P<0,05)$ entre os teores de FDA e PB dos cultivares. Para o FDA apenas 0 8050-Agromen se diferenciou apresentando o menor valor $\left(87 \mathrm{~g} \mathrm{~kg}^{-1}\right)$. Quanto à $\mathrm{PB}$, a maior média foi obtida pelo 8050-Agromen que apresentou $109 \mathrm{~g} \mathrm{~kg}^{-1}$, embora a diferença não tenha sido significativa em relação à maioria dos cultivares $(P>0,05)$. $O$ único cultivar que apresentou menor concentração de PB no grão foi 8419-Piooner, com média de $86 \mathrm{~g} \mathrm{~kg}^{-1}(P<0,05)$.

$\mathrm{O}$ volume total de gases produzido em 24 e $96 \mathrm{~h}$ (bioensaio) e o acréscimo no volume de gases obtido através da dição de PEG para os cortes aos 30, 60, 90 e 120 dias podem ser vistos na Tabela 1. Foram encontradas diferenças significativas entre os cultivares em relação ao volume acumulado de gases em $24 \mathrm{~h}$ de incubação para as idades de 30 e 120 dias $(P<0,05)$.

Aos 30 dias o BRS305 foi o cultivar que produziu menor volume de gases, enquanto que o maior volume foi produzido pelo 8050-Agromen. Aos 120 dias, a maior média foi encontrada para o BR306 e o menor volume produzido pelo 8118-Piooner.

O bioensaio foi avaliado através dos acréscimos de produção de gases obtidos entre as amostras incubadas com e sem PEG no tempo de $24 \mathrm{~h}$ (incremento). Foram observados acréscimos para todas as idades estudadas com exceção de 90 dias. Neste período a maioria dos cultivares apresentou resultados negativos.

A Tabela 2 mostra os principais parâmetros do modelo de France et al. (1993) e a degradabilidade da MS obtidos após 96 h de fermentação. 
Tabela 1. Volume de gases acumulado em 24 e $96 h$ de incubação e incremento da produção de gases obtidos através do bioensaio de oito cultivares de sorgo aos 30, 60, 90 e 120 dias de idade.

\begin{tabular}{|c|c|c|c|}
\hline \multirow{3}{*}{ Híbridos } & $V 24 h^{1}$ & V96h ${ }^{1}$ & Incremento(24h) ${ }^{2}$ \\
\hline & \multicolumn{3}{|c|}{ Idade } \\
\hline & \multicolumn{2}{|c|}{30 dias } & \\
\hline BRS701 & $30 \pm 14^{\mathrm{ab}}$ & $180 \pm 21$ & 2 \\
\hline 8118 - Piooner & $36 \pm 18^{a b}$ & $181 \pm 20$ & 4 \\
\hline BR306 & $38 \pm 11^{\mathrm{ab}}$ & $174 \pm 10$ & -7 \\
\hline Saara - Monsanto & $28 \pm 15^{\mathrm{ab}}$ & $166 \pm 19$ & 11 \\
\hline 8050 - Agromen & $42 \pm 20^{a}$ & $178 \pm 18$ & 8 \\
\hline$B R 700$ & $30 \pm 9^{a b}$ & $165 \pm 14$ & 8 \\
\hline BRS305 & $24 \pm 11^{b}$ & $164 \pm 12$ & 29 \\
\hline 8419 - Piooner & $27 \pm 8^{\mathrm{ab}}$ & $168 \pm 14$ & 15 \\
\hline \multicolumn{4}{|c|}{60 dias } \\
\hline BRS701 & $28 \pm 8$ & $157 \pm 4$ & -12 \\
\hline 8118 - Piooner & $35 \pm 8$ & $171 \pm 18$ & -6 \\
\hline BR306 & $26 \pm 3$ & $152 \pm 12$ & -13 \\
\hline Saara - Monsanto & $28 \pm 3$ & $158 \pm 6$ & -6 \\
\hline 8050 - Agromen & $29 \pm 13$ & $164 \pm 11$ & -8 \\
\hline$B R 700$ & $23 \pm 3$ & $157 \pm 4$ & -12 \\
\hline BRS305 & $26 \pm 6$ & $153 \pm 12$ & 0 \\
\hline 8419 - Piooner & $32 \pm 7$ & $165 \pm 7$ & -2 \\
\hline \multicolumn{4}{|c|}{90 dias } \\
\hline BRS701 & $40 \pm 4$ & $173 \pm 8$ & 16 \\
\hline 8118 - Piooner & $51 \pm 5$ & $177 \pm 13$ & 6 \\
\hline BR306 & $44 \pm 6$ & $177 \pm 9$ & 8 \\
\hline Saara - Monsanto & $55 \pm 7$ & $185 \pm 7$ & 9 \\
\hline 8050 - Agromen & $51 \pm 21$ & $171 \pm 56$ & 32 \\
\hline BR700 & $48 \pm 5$ & $175 \pm 11$ & 2 \\
\hline BRS305 & $54 \pm 6$ & $186 \pm 14$ & -1 \\
\hline 8419 - Piooner & $53 \pm 12$ & $171 \pm 14$ & 11 \\
\hline \multicolumn{4}{|c|}{120 dias } \\
\hline BRS701 & $75 \pm 7^{a b}$ & $175 \pm 23$ & -4 \\
\hline 8118 - Piooner & $49 \pm 12^{b}$ & $181 \pm 21$ & 6 \\
\hline$B R 306$ & $79 \pm 23^{a}$ & $186 \pm 9$ & -1 \\
\hline Saara - Monsanto & $61 \pm 7^{\mathrm{ab}}$ & $180 \pm 5$ & -5 \\
\hline 8050 - Agromen & $74 \pm 4^{\mathrm{ab}}$ & $208 \pm 11$ & -6 \\
\hline$B R 700$ & $60 \pm 17^{a b}$ & $171 \pm 19$ & 0 \\
\hline BRS305 & $67 \pm 10^{a b}$ & $183 \pm 23$ & 5 \\
\hline 8419 - Piooner & $67 \pm 17^{\mathrm{ab}}$ & $182 \pm 21$ & 7 \\
\hline
\end{tabular}


Tabela 2. Produção de gases potencial $\left(V_{f}\right)$, lag time $\left(t_{0}\right)$ e degradabilidade "in vitro" (D96h) de oito cultivares de sorgo aos 30,60, 90 e 120 dias após o plantio.

\begin{tabular}{|c|c|c|c|}
\hline \multirow[b]{2}{*}{ Híbridos } & $V_{f}^{1}$ & $t_{0}^{2}$ & $D 96 h^{3}$ \\
\hline & \multicolumn{3}{|c|}{ Idade } \\
\hline \multicolumn{4}{|c|}{30 dias } \\
\hline BRS701 & $196 \pm 30$ & $11 \pm 5$ & $76 \pm 3$ \\
\hline 8118 - Piooner & $194 \pm 22$ & $11 \pm 3$ & $75 \pm 3$ \\
\hline BR306 & $184 \pm 11$ & $9 \pm 2$ & $76 \pm 4$ \\
\hline Saara - Monsanto & $178 \pm 18$ & $11 \pm 2$ & $74 \pm 2$ \\
\hline 8050 - Agromen & $186 \pm 17$ & $9 \pm 3$ & $75 \pm 3$ \\
\hline$B R 700$ & $177 \pm 13$ & $10 \pm 2$ & $74 \pm 2$ \\
\hline BRS305 & $179 \pm 18$ & $11 \pm 2$ & $76 \pm 2$ \\
\hline 8419 - Piooner & $183 \pm 11$ & $11 \pm 2$ & $74 \pm 1$ \\
\hline \multicolumn{4}{|c|}{60 dias } \\
\hline BRS701 & $180 \pm 16$ & $8 \pm 4^{a b}$ & $69 \pm 2^{b}$ \\
\hline 8118 - Piooner & $184 \pm 7$ & $6 \pm 2^{b}$ & $67 \pm 1^{c}$ \\
\hline BR306 & $187 \pm 53$ & $8 \pm 3^{a b}$ & $70 \pm 2^{a b}$ \\
\hline Saara - Monsanto & $183 \pm 23$ & $7 \pm 3^{a b}$ & $68 \pm 2^{b c}$ \\
\hline 8050 - Agromen & $178 \pm 8$ & $10 \pm 4^{a b}$ & $73 \pm 1^{a}$ \\
\hline$B R 700$ & $176 \pm 5$ & $11 \pm 3^{a}$ & $67 \pm 2^{b c}$ \\
\hline BRS305 & $178 \pm 15$ & $9 \pm 2^{a b}$ & $65 \pm 2^{c}$ \\
\hline 8419 - Piooner & $183 \pm 4$ & $7 \pm 1^{\mathrm{ab}}$ & $65 \pm 3^{c}$ \\
\hline \multicolumn{4}{|c|}{90 dias } \\
\hline BRS701 & $195 \pm 11$ & $5 \pm 1$ & $62 \pm 1^{c}$ \\
\hline 8118 - Piooner & $194 \pm 12$ & $4 \pm 0,3$ & $63 \pm 3^{b c}$ \\
\hline BR306 & $204 \pm 12$ & $5 \pm 1$ & $63 \pm 2^{b c}$ \\
\hline Saara - Monsanto & $201 \pm 10$ & $5 \pm 1$ & $65 \pm 3^{a b}$ \\
\hline 8050 - Agromen & $185 \pm 61$ & $5 \pm 2$ & $66 \pm 3^{a}$ \\
\hline$B R 700$ & $200 \pm 16$ & $4 \pm 0,5$ & $63 \pm 1^{b c}$ \\
\hline BRS305 & $209 \pm 24$ & $4 \pm 2$ & $63 \pm 2^{b c}$ \\
\hline 8419 - Piooner & $188 \pm 11$ & $4 \pm 1$ & $60 \pm 2^{c}$ \\
\hline \multicolumn{4}{|c|}{120 dias } \\
\hline BRS701 & $208 \pm 11$ & $2 \pm 1$ & $65 \pm 4^{a b c}$ \\
\hline 8118 - Piooner & $203 \pm 9$ & $3 \pm 1$ & $62 \pm 4^{c}$ \\
\hline BR306 & $212 \pm 12$ & $2 \pm 1$ & $67 \pm 2^{a}$ \\
\hline Saara - Monsanto & $202 \pm 22$ & $4 \pm 1$ & $67 \pm 3^{a b}$ \\
\hline 8050 - Agromen & $215 \pm 3$ & $3 \pm 0,4$ & $69 \pm 2^{a}$ \\
\hline$B R 700$ & $206 \pm 11$ & $3 \pm 2$ & $61 \pm 3^{c}$ \\
\hline BRS305 & $208 \pm 6$ & $3 \pm 1$ & $62 \pm 4^{b c}$ \\
\hline 8419 - Piooner & $200 \pm 12$ & $3 \pm 1$ & $61 \pm 2^{c}$ \\
\hline
\end{tabular}

${ }^{1} \mathrm{ml}$ de gás; ${ }^{2} h,{ }^{3} \%$

${ }^{a, b, c}$ médias seguidas de letras diferentes na coluna diferem entre si pelo teste de Tukey com $5 \%$ de probabilidade 
Em relação ao potencial de produção de gases, todos os cultivares apresentaram comportamentos semelhantes. O tempo de colonização do substrato pelos microrganismos ou lag time foi diferente entre os cultivares $(\mathrm{P}<0,05)$ apenas para a idade de 60 dias.

Nesta idade, o cultivar BR700 apresentou o maior tempo de colonização, enquanto que o 8114-Piooner foi o mais rapidamente colonizado. Os cultivares apresentaram diferenças significativas $(P<0,05)$ em relação a degradabilidade da MS em $96 \mathrm{~h}$ em todas as idades estudadas, exceto aos 30 dias.

Aos 60 dias, o 8050-Agromen apresentou a maior taxa de desaparecimento da matéria seca, seguido do BR306 e do BR701. O BRS305 e o 8419-Piooner apresentaram as menores médias de D96h nesta fase. Com 90 dias, o 8050-Agromen e o Saara-Monsanto apresentaram os maiores valores de degradabilidade, sendo que o 8419-Piooner e o BR701 mostraram os menores valores.

Os cultivares 8050-Agromen, BR306, Saara-Monsanto e o BR701 apresentaram as maiores médias de degradabilidade aos 120 dias, não havendo diferenças estatísticas entre as mesmas. Os menores valores foram obtidos para o BR700, o 8419-Piooner e o 8118-Piooner.

Os resultados da produção de gases obtidos com 24 e $96 \mathrm{~h}$ de incubação e os incrementos dos gases obtidos com os grãos estão representados na Tabela 3.

Em relação ao volume de gases produzidos durante 24 e $96 \mathrm{~h}$ e ao volume potencial $\left(\mathrm{V}_{\mathrm{f}}\right)$ estimado, as diferenças encontradas entre os cultivares $(P<0,05)$ foram maiores para o BR306 e o 8050-Agromen. Os menores valores foram obtidos para o BRS305 e BRS701. Não foram encontradas diferenças $(P<0,05)$ nos tempos de colonização entre os cultivares, sendo $4 \pm 0,93 \mathrm{~h} \circ$ tempo médio obtido.

As maiores médias de degradabilidade da MS foram encontradas para os cultivares 8050-Agromen e Saara-Monsanto $(P<0,05)$. Os valores médios obtidos para o incremento de produção de gases variaram de 20 a $23 \%$. 
Tabela 3. Volume de gases acumulado em 24 e 96 h de incubação, produção de gases potencial $\left(V_{f}\right)$, lag time $\left(t_{0}\right)$, degradabilidade "in vitro" (D96h) e incremento da produção de gases dos grãos de oito cultivares de sorgo.

\begin{tabular}{l|cccccc}
\hline Cultivares & $V 24 h^{1}$ & $V 96 h^{1}$ & $V_{f}^{1}$ & $t_{o}{ }^{2}$ & $D 96 h^{3}$ & Incr. $^{3}$ \\
\hline BRS701 & $150 \pm 48$ & $322 \pm 28^{\mathrm{b}}$ & $328 \pm 28^{\mathrm{b}}$ & $5 \pm 2$ & $83 \pm 3^{\mathrm{bc}}$ & 20 \\
8118 - Piooner & $147 \pm 15$ & $370 \pm 28^{\mathrm{ab}}$ & $395 \pm 25^{\mathrm{ab}}$ & $4 \pm 1$ & $85 \pm 4^{\mathrm{ab}}$ & 17 \\
BR306 & $217 \pm 38$ & $430 \pm 113^{\mathrm{a}}$ & $436 \pm 117^{\mathrm{a}}$ & $4 \pm 2$ & $85 \pm 4^{\mathrm{ab}}$ & -20 \\
Saara - Monsa. & $179 \pm 20$ & $396 \pm 49^{\mathrm{ab}}$ & $407 \pm 55^{\mathrm{ab}}$ & $3 \pm 2$ & $89 \pm 1^{\mathrm{a}}$ & -4 \\
8050 - Agromen & $160 \pm 30$ & $415 \pm 24^{\mathrm{ab}}$ & $438 \pm 24^{\mathrm{a}}$ & $5 \pm 1$ & $90 \pm 1^{\mathrm{a}}$ & -12 \\
BR700 & $185 \pm 44$ & $386 \pm 46^{\mathrm{ab}}$ & $390 \pm 45^{\mathrm{ab}}$ & $5 \pm 2$ & $84 \pm 5^{\mathrm{bc}}$ & 6 \\
BRS305 & $168 \pm 22$ & $322 \pm 21^{\mathrm{b}}$ & $325 \pm 22^{\mathrm{b}}$ & $3 \pm 1$ & $80 \pm 5^{\mathrm{c}}$ & 23 \\
8419 - Piooner & $190 \pm 29$ & $367 \pm 18^{\mathrm{ab}}$ & $367 \pm 20^{\mathrm{ab}}$ & $3 \pm 1$ & $84 \pm 4^{\mathrm{bc}}$ & 11 \\
${ }^{{ }^{7} \mathrm{ml}^{2}{ }^{2}{ }^{3} \%}$ \\
a,bec ${ }^{3}$ médias seguidas de letras diferentes na coluna diferem entre si pelo teste de Tukey com $5 \%$ de probabilidade
\end{tabular}

Através do modelo de France et al. (1993) foi possível obter o perfil fermentativo das oito cultivares nas diferentes fases de desenvolvimento (Figuras 7, 8, 9, 10 e 11) sem ou com a adição do polipropileno glicol (PEG).

As concentrações médias de TC nos grão foram de 2,2 $\pm 0,3 \%$ para o BRS701; $0 \%$ para o 8118-Piooner; $1,5 \pm$ 0,2 \% para o BR306; $0 \%$ para o Saara-Monsanto; $0 \%$ para o 8050-Agromen; 1,6 \pm 0,2 \% para o BR700; 3,3 \pm 0,2 \% para o BRS305 e 2,1 \pm 0,3 \% para o 8419-Piooner. Os valores de TC encontrados para o BRS305 foram considerados maiores do que os demais cultivares pelo teste de Tukey $(P<0,05)$. Não foi encontrada diferença estatística entre o BR701 e o 8419-Piooner. O mesmo aconteceu entre o 8419-Piooner, o 8118-Piooner e o BR700 ( $P>0,05)$. Os valores obtidos para o 8050-Agromen, o BR306 e o Saara-Monsanto foram considerados diferentes dos demais $(\mathrm{P}<0,05)$. 
O cultivar BRS305 apresentou a maior concentração de TC, seguido do 8419-Piooner e do BRS701 $(\mathrm{P}<0,05)$. A presença do TC não foi detectada em alguns dos cultivares estudados. 
BRS 701

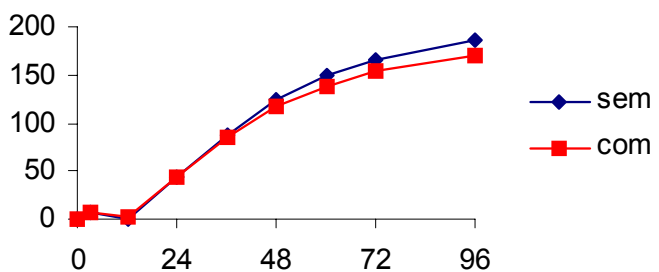

BR306

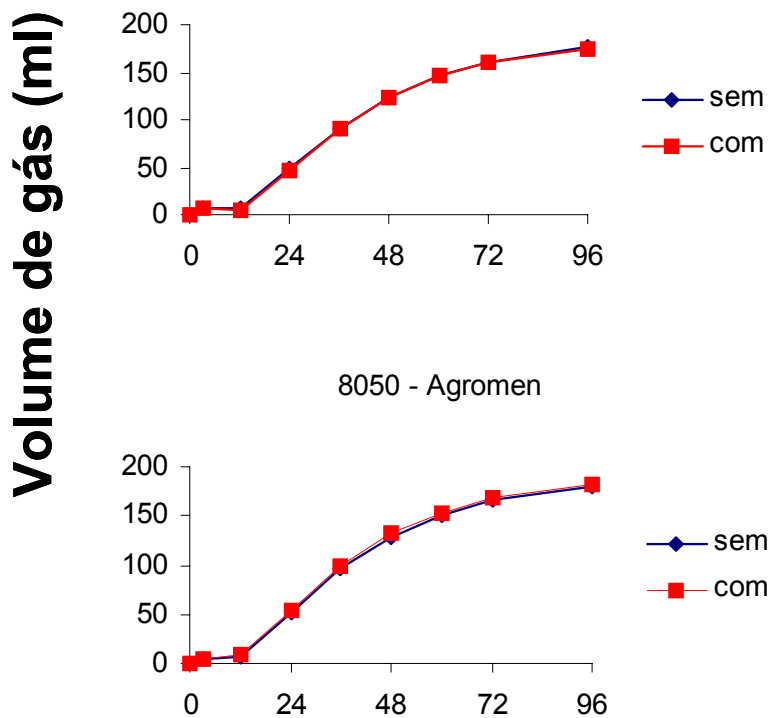

BRS305

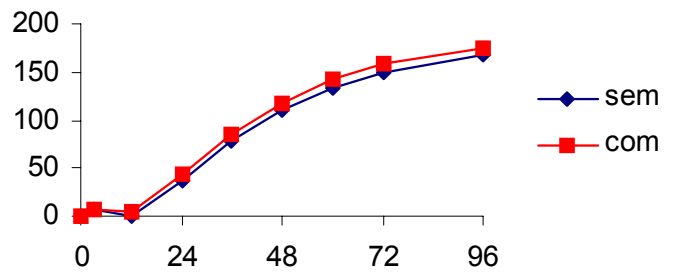

8118 - Piooner

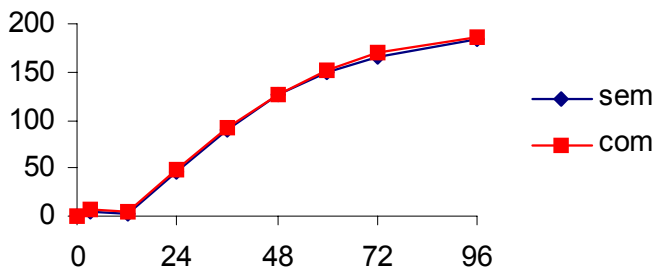

Saara - Monsanto

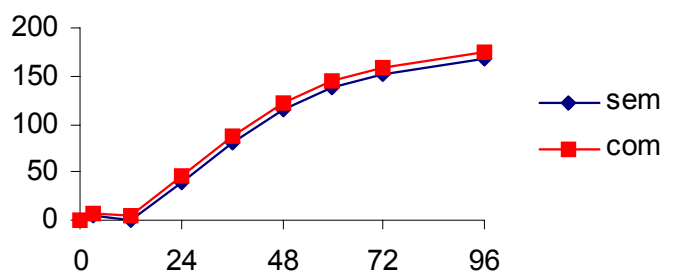

BR700

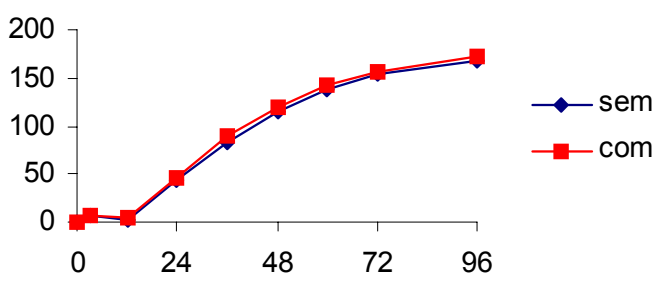

8419 - Piooner

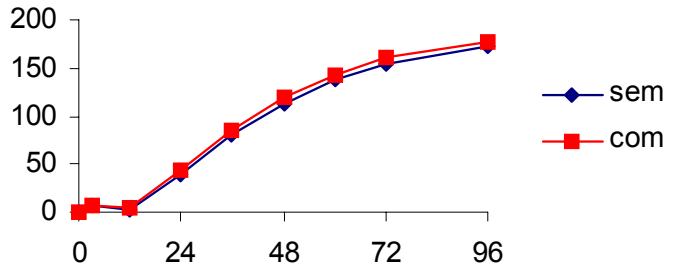

\section{Tempo (h)}

Figura 8. Perfil da fermentação ruminal in vitro de 8 cultivares de sorgo colhidos aos 30 dias após o plantio. 
BRS 701

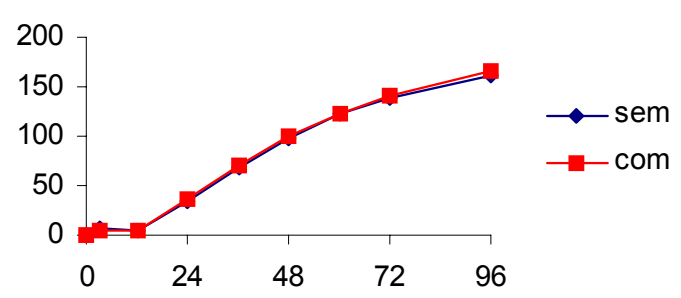

BR306

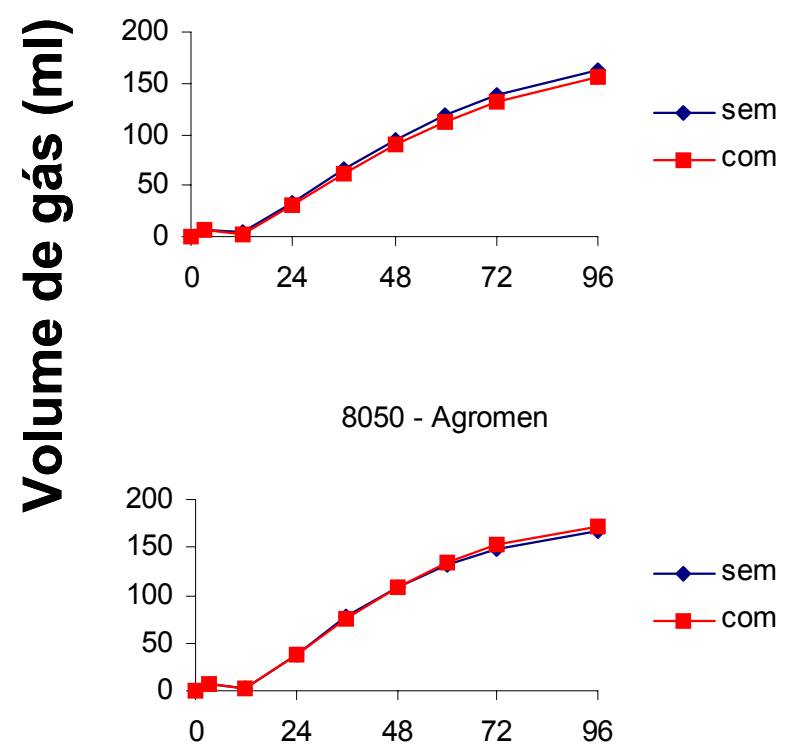

BRS305

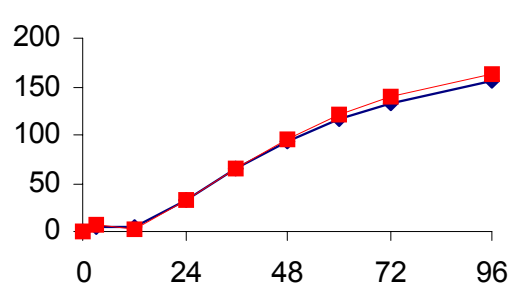

8118 - Piooner

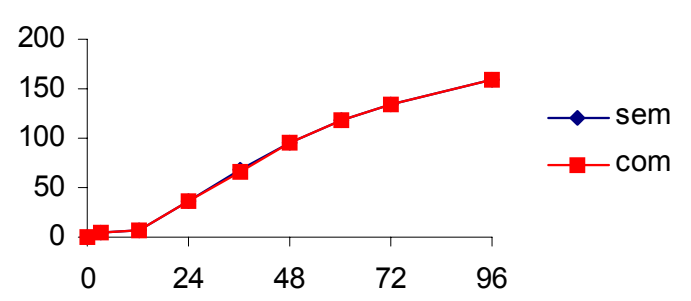

Saara - Monsanto

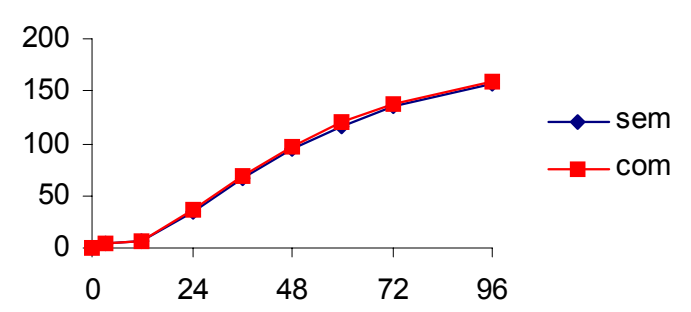

BR700

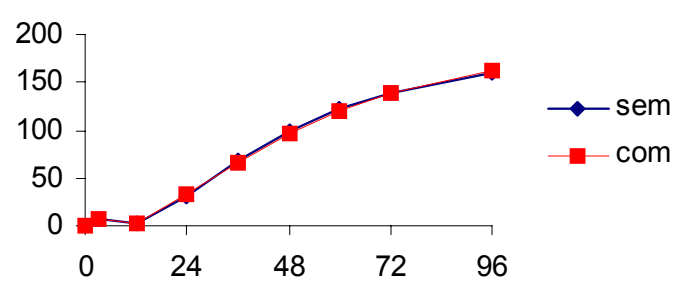

8419 - Piooner

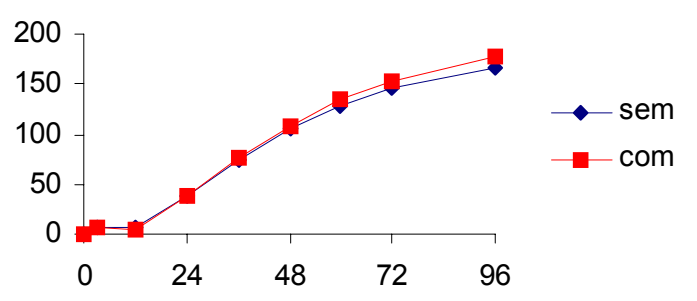

\section{Tempo (h)}

Figura 9. Perfil da fermentação ruminal in vitro de 8 cultivares de sorgo colhidos aos 60 dias após o plantio. 
BRS701

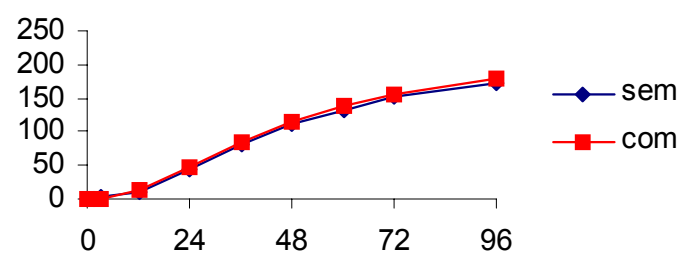

BR306

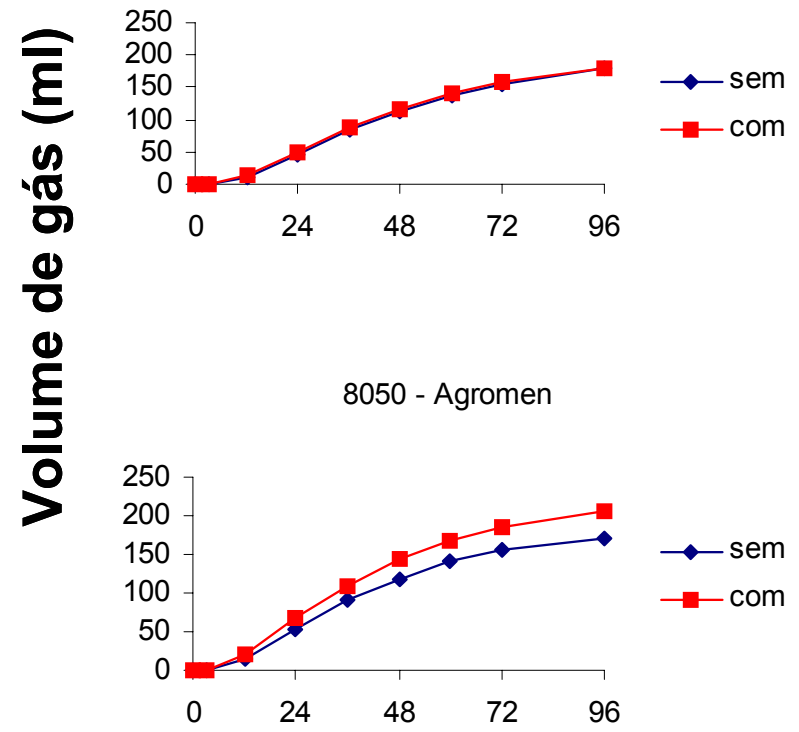

BRS305

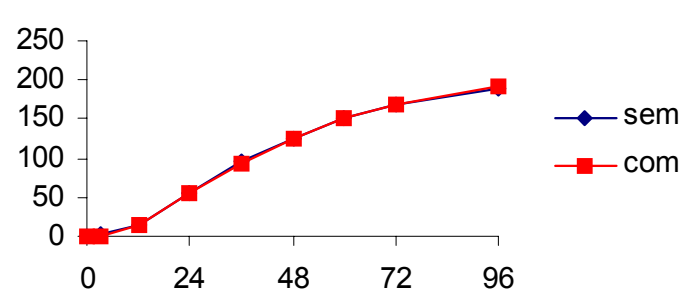

8118 - Piooner

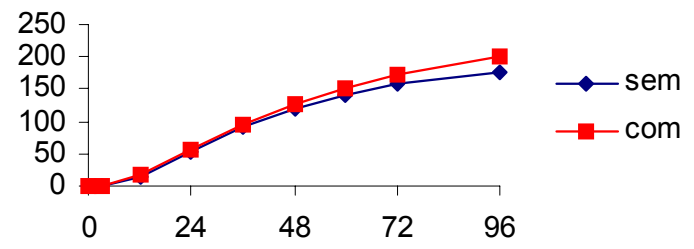

Saara - Monsanto

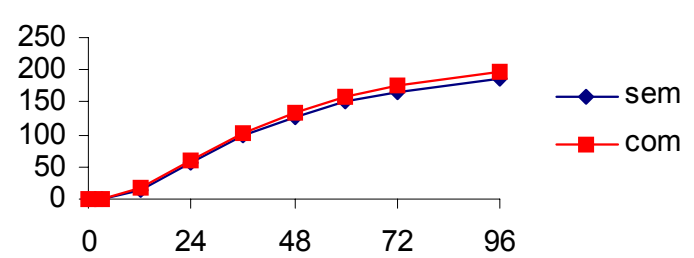

BR700

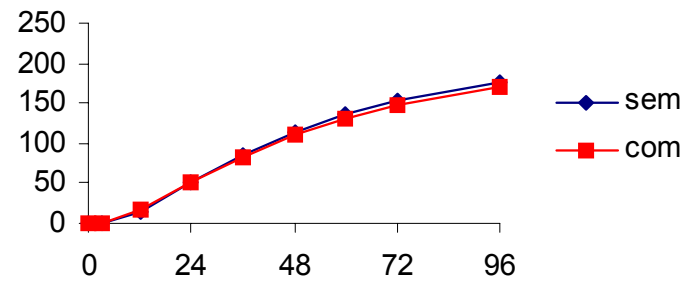

8419 - Piooner

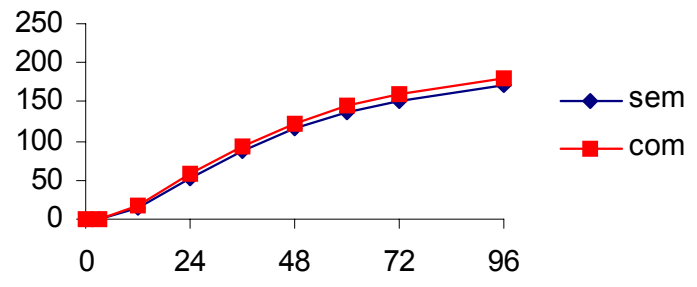

\section{Tempo (h)}

Figura 10. Perfil da fermentação ruminal in vitro de 8 cultivares de sorgo colhidos aos 90 dias após o plantio. 
BRS701

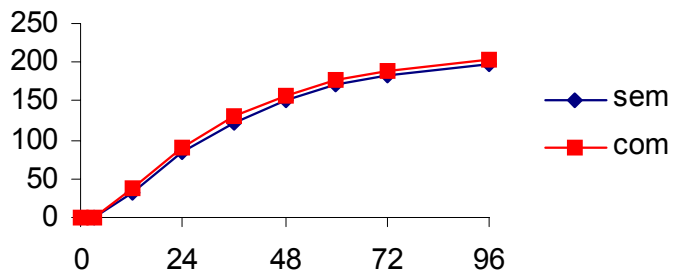

BR306

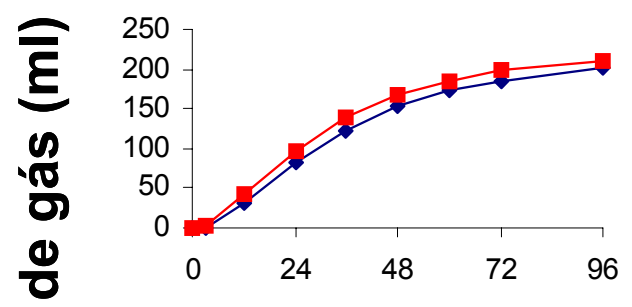

8050 - Agromen

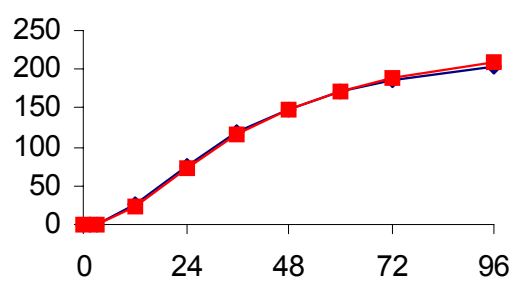

BRS305

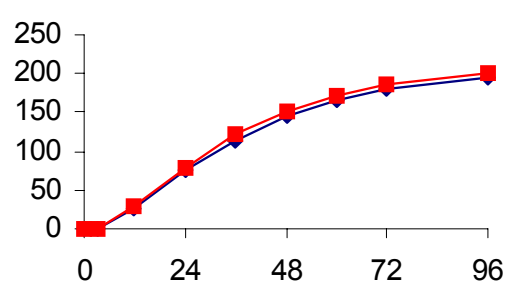

8118 - Piooner

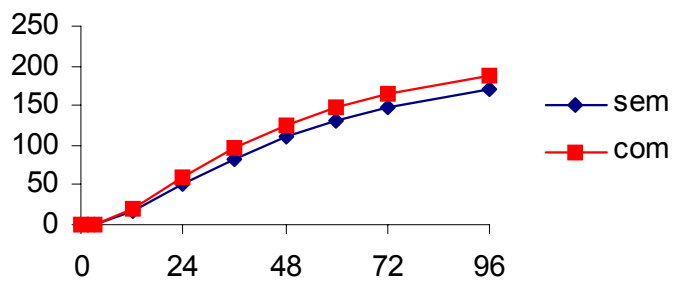

Saara - Monsanto

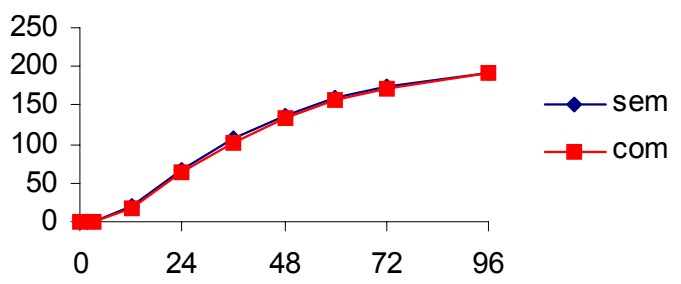

BR700

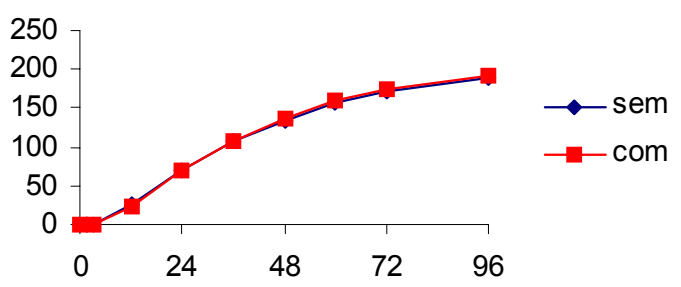

8419 - Piooner

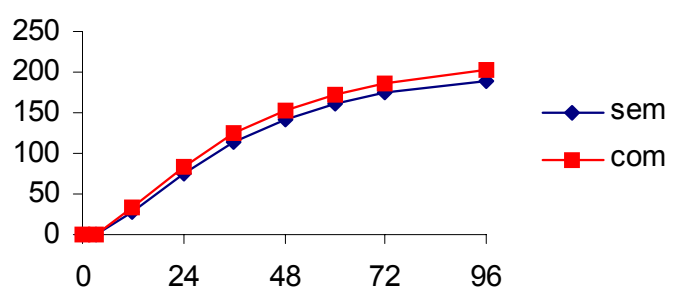

\section{Tempo (h)}

Figura 11. Perfil da fermentação ruminal in vitro de 8 cultivares de sorgo colhidos aos 120 dias após o plantio. 
BRS701

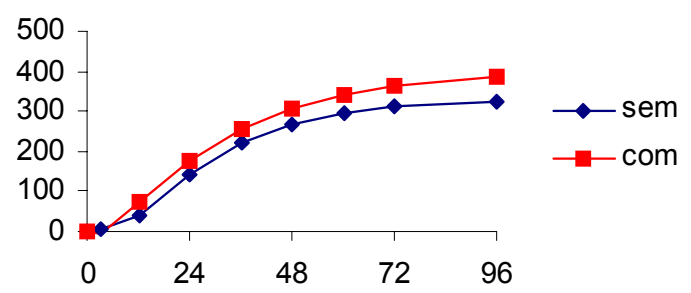

BR306

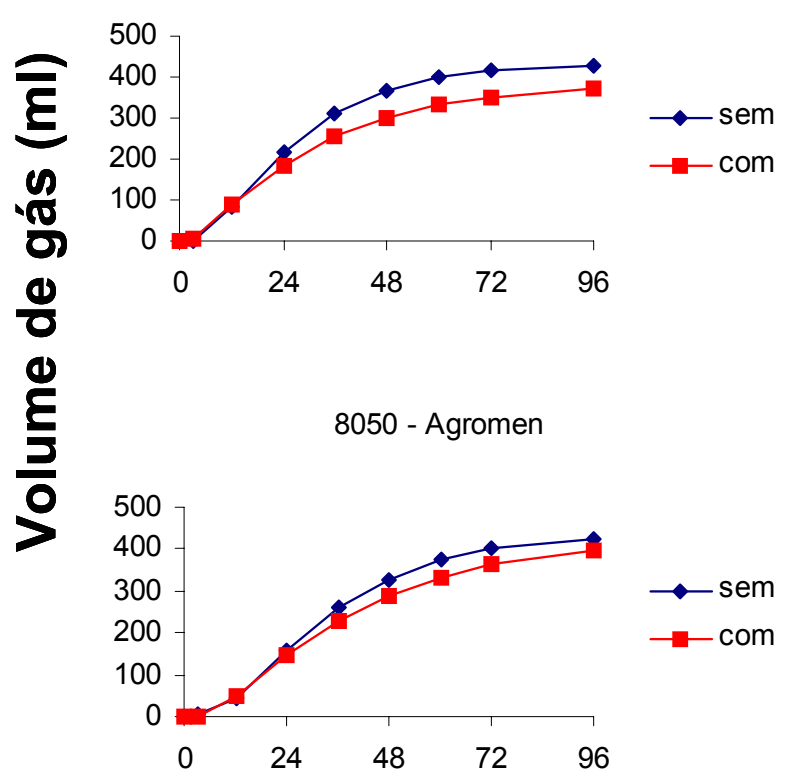

BRS305

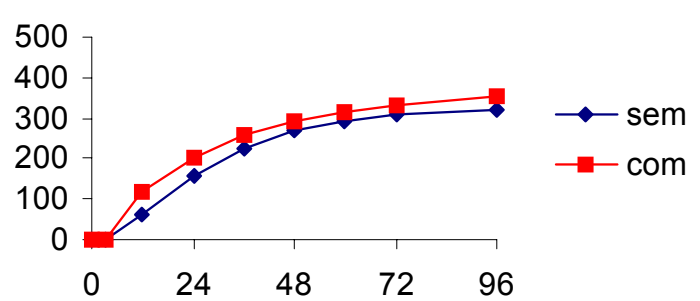

8118 - Piooner

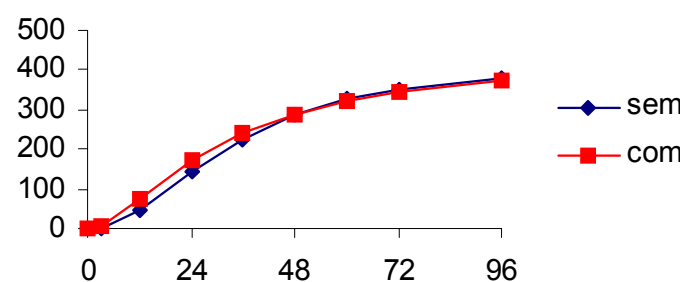

Saara - Monsanto
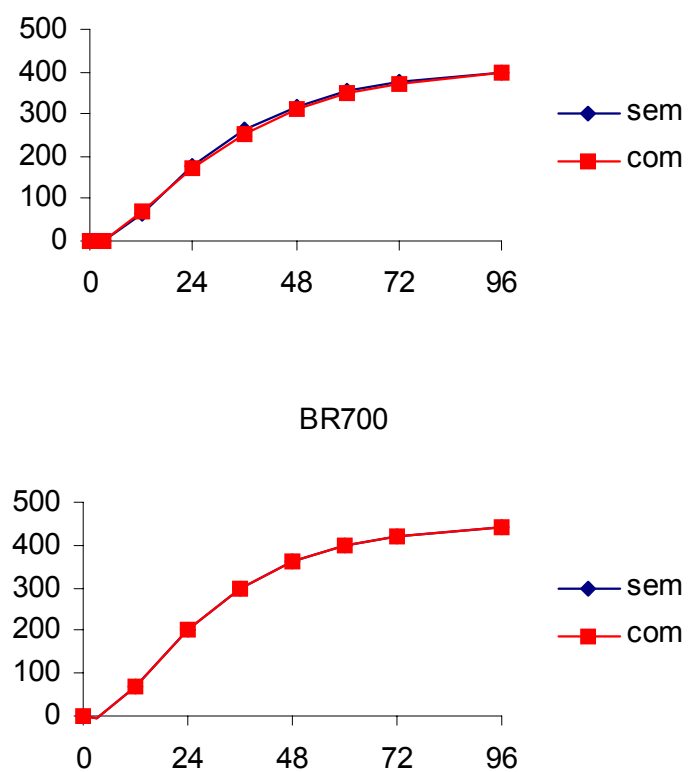

8419 - Piooner

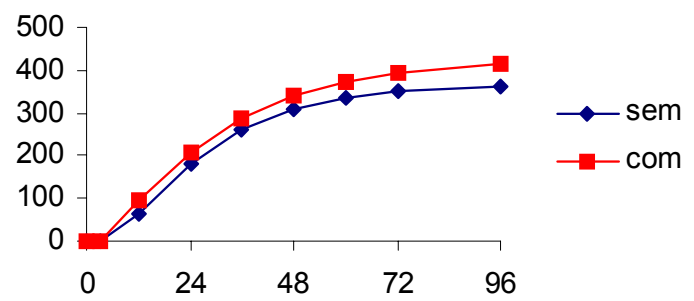

\section{Tempo (h)}

Figura 12. Perfil da fermentação ruminal in vitro dos grãos de 8 cultivares de sorgo . 
A análise de regressão entre as concentrações de taninos condensados e o incremento da produção de gases $\left(R^{2}=0,56 ; P<0,05\right)$ está representada na Figura 13. O incremento do volume de gases apresentou correlação positiva $(r=0,75)$ com as concentrações de TC nos grãos para sete dos oito cultivares estudados. O cultivar 8118-Piooner foi retirado da análise por ter apresentado resultados inconsistentes em relação ao incremento de gases $(17 \%)$ e os teores de TC $(0 \%)$.

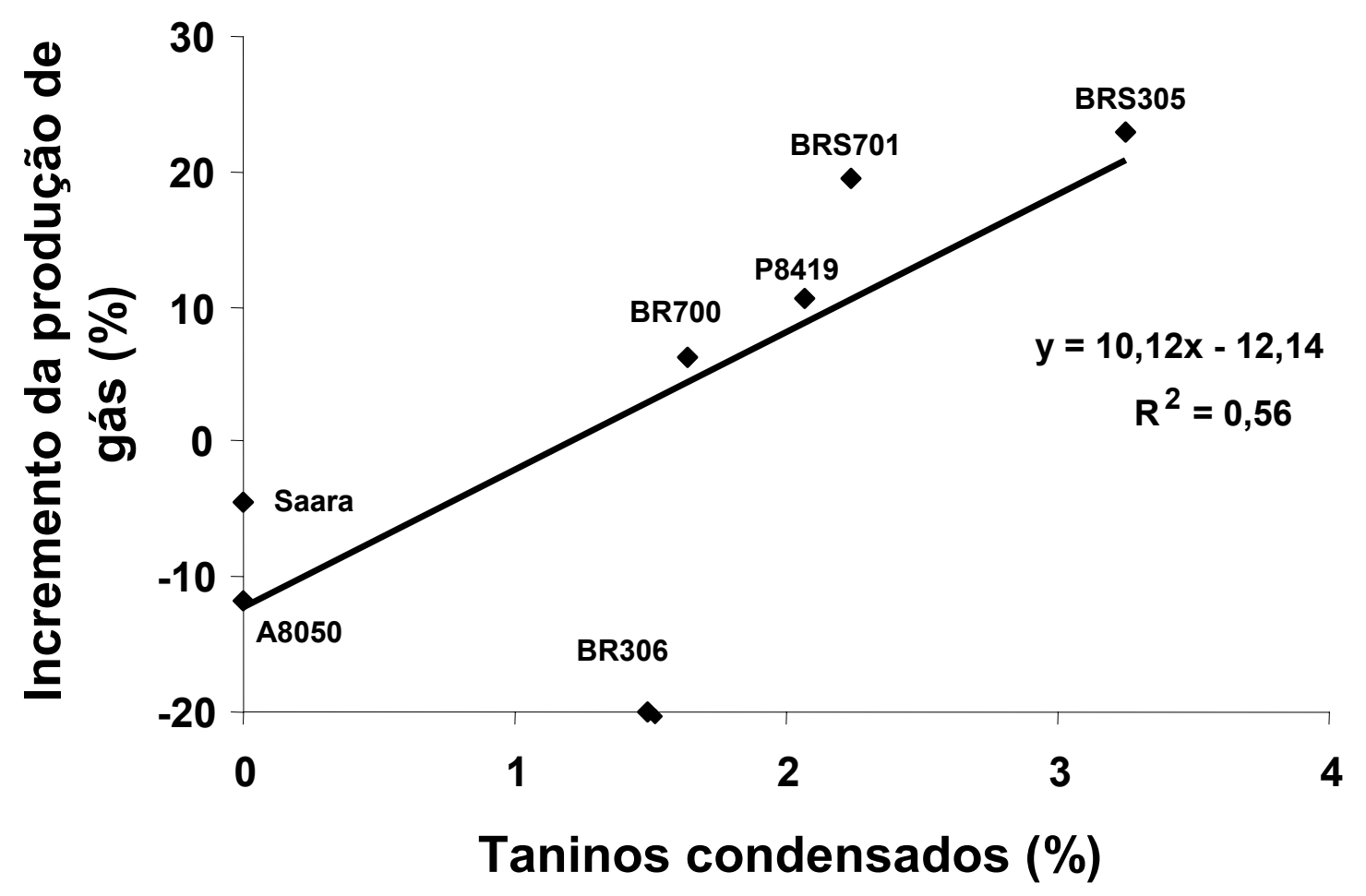

Figura 13. Regressão linear entre as concentrações de taninos condensados nos grãos de diferentes cultivares de sorgo e os incrementos das produções de gases in vitro com a adição do polietileno glicol (PEG). 
A D96h apresentou um comportamento linear negativo (Figuras 14 e 15) com as concentrações de TC $\left(R^{2}=0,79 ; P<0,05\right)$ e com o incremento da produção de gases obtido através do bioensaio $\left(R^{2}=0,49 ; P<0,05\right)$.

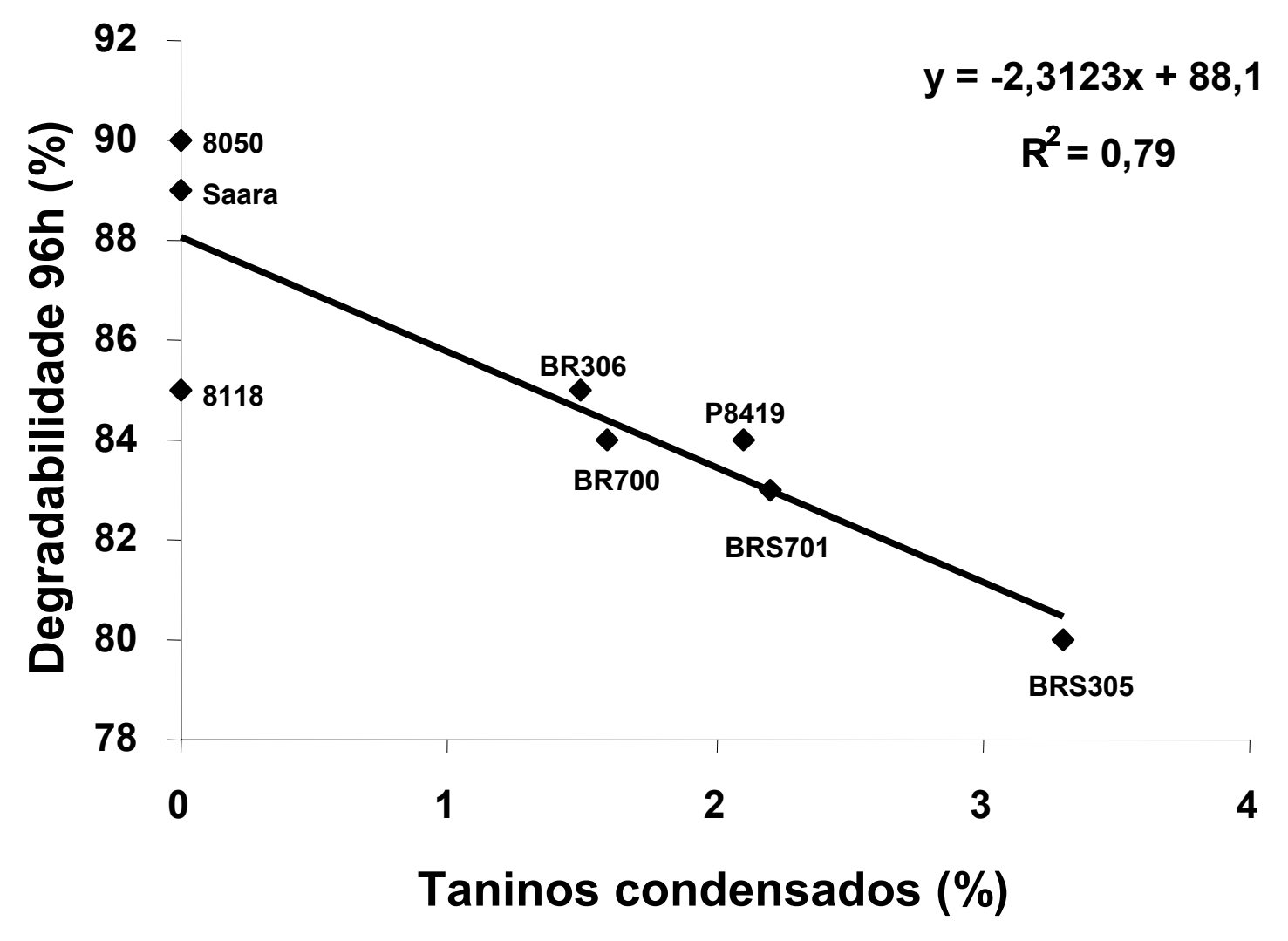

Figura 14. Regressão linear entre as concentrações de taninos condensados nos grãos de diferentes cultivares de sorgo e a degradabilidade da MS após 96 horas de incubação. 


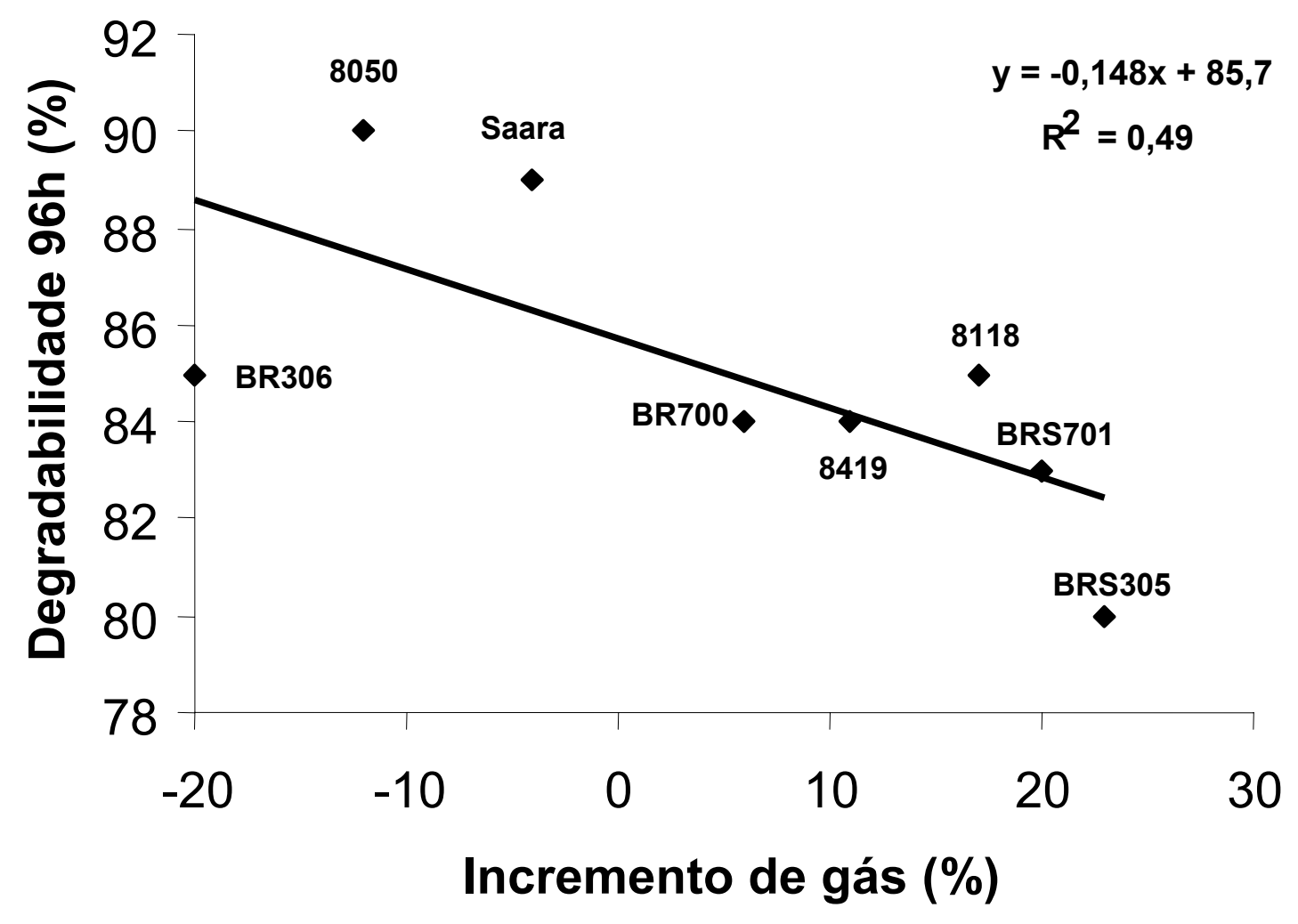

Figura 15. Regressão linear entre as concentrações de taninos condensados nos grãos de alguns cultivares de sorgo e o incremento da produção de gases in vitro com a adição do polietileno glicol (PEG).

\subsection{Discussão}

De acordo com os resultados das análises químicas (Figuras 5, 6 e 7), aos 30 dias de idade todos os cultivares apresentaram valores nutricionais semelhantes. As avaliações in vitro também seguiram a mesma tendência, mostrando algumas diferenças apenas no volume de gases após 24 h (V24h). 
A maior proporção de folhas em relação aos caules contribuiram para as semelhanças encontradas nesta idade. Aos 30 dias os cultivares ainda não haviam demonstrado diferenças quanto ao seu propósito (forrageiro ou granífero).

A Figura 5 mostra com clareza as maiores concentrações de minerais aos 30 dias de idade e o decréscimo das mesmas de acordo com a maturação fisiológica da planta. McDowell et al. (2000) cita a maturação fisiológica como uma das variáveis que podem afetar as concentrações de minerais das forragens. O trabalho de Gomide et al. (1969) com diferentes forrageiras no Brasil, demonstrou diminuições nas concentrações de minerais com o aumento da idade das plantas.

Os valores de degradabilidade da matéria seca (D96h) foram elevados aos 30 dias, indicando um bom potencial de uso da planta nesta idade para o pastejo.

Em comparação a outras forrageiras, Gerdes et al. (2000) encontraram valores médios de $72 \%$ para digestibilidade in vitro em pastagens de Brachiaria brizantha cv. Marandú aos 35 dias. Campos et al. (2002), medindo a produção de gases do capim elefante (Pennisetum purpureum), encontraram valores de degradabilidade de $81 \%$ aos 45 dias.

Aos 60 e 90 dias as plantas apresentavam diferenças nutricionais entre os cultivares. Quanto à composição química, os cultivares graníferos apresentaram valores nutritivos superiores aos forrageiros, com menores concentrações de FDA. Embora os cultivares graníferos apresentem melhores características nutricionais, Nussio \& Mansano (1999) ressaltam a maior capacidade de produção de nutrientes por área dos cultivares forrageiros.

Os parâmetros de produção de gases não apresentaram diferenças nesta idade, com exceção do tempo de colonização estimado (tempo "lag"). O maior tempo de colonização foi encontrado para o cultivar BR700 e pode estar relacionado com as maiores concentrações de FDA encontradas neste cultivar. 
As diferenças na degradabilidade da matéria seca demonstraram a superioridade dos cultivares graníferos. Valores de D96h próximos de $60 \%$, também foram encontrados por outros autores (Campos et al. 2002; Cabral et al., 2003, Souza et al. 2003) que mediram a digestibilidade in vitro e in situ da silagem de diferentes cultivares de sorgo (alto e baixo tanino).

Gontijo Neto et al. (2002) determinaram a digestibilidade in vitro da matéria seca de cinco cultivares de sorgo forrageiros e de duplo propósito. As plantas foram cortadas a $15 \mathrm{~cm}$ do solo no estágio de grãos farináceo, sendo que a maior média de digestibilidade encontrada foi de $61,69 \%$ para o AG2005E.

Maurício et al. (2003) mediram a produção de gases da silagem de quatro cultivares (BR700, BR701, BR601 e AG2002) obtendo valores de 179, 179, 194 e $166 \mathrm{ml} \mathrm{g}^{-1}$ MS para o $\mathrm{V}_{f}$ e 60, 60, 65 e $59 \%$ para D96h, respectivamente.

Aos 120 dias houve um aumento nos parâmetros de produção de gases em relação às idades anteriores. Alguns cultivares se diferenciaram, como foi o caso do BR306. Estas diferenças foram encontradas em V24h e D96h e estão relacionadas com as maiores quantidades de grãos presentes em alguns cultivares nesta fase. Nota-se que os cultivares que apresentaram melhor desempenho (BR306 e 8050-Agromen) são graníferos, com exceção do BRS701 que mostrou um dos maiores valores para D96h. Indicado para silagem, este cultivar é classificado pela EMBRAPA como duplo-propósito.

Os teores de PB diminuíram com o aumento da idade das plantas. A diminuição da proteína está relacionada com a menor proporção de folhas em relação ao caule devido ao amadurecimento das plantas. Um estudo com sete cultivares da Índia em diferentes fases de crescimento apresentou uma diminuição na concentração de proteína e na digestibilidade da matéria seca com o aumento da idade da planta (Sultan et al., 2003).

Em relação aos grãos, os cultivares apresentaram variações significativas nos teores de PB. Estas diferenças estão de acordo com os 
trabalhos de Ruskin (1996) e Valadares (2002), que apontaram variações nos teores de PB de 80 a $150 \mathrm{~g} \mathrm{~kg}^{-1}$, estudando cultivares dos Estados Unidos e do Brasil.

Outras diferenças em relação aos grãos foram observadas para o V96h e a D96h. Os cultivares com maiores concentrações de TC apresentaram os piores resultados para V96h e D96h. As diminuições da digestibilidade in vitro e in situ foram descritas por Rodrigues et al. (1999) e Campos et al. (2003) que trabalharam com cultivares de sorgo com diferentes teores de taninos.

O bioensaio apresentou resultados diferentes entre as idades estudadas. Os incrementos na produção de gases observados aos 30 e aos 90 dias não apresentaram correlação com as concentrações de TC obtidas a partir das análises químicas, que revelaram baixas concentrações de TC $(\cong 0)$ para todos os cultivares nos primeiros cortes.

As curvas de fermentação estimadas a partir do modelo de France et al. (1993) mostram comportamentos semelhantes entre as amostras com e sem a adição do PEG (Figuras 8, 9, 10, 11 e 12).

Maiores concentrações de TC foram encontradas a partir dos 120 dias que estão relacionadas com as maiores quantidades de grãos nas plantas. Os incrementos na produção de gases obtidos aos 30 e 90 dias na presença do PEG não apresentaram correlações com as concentrações de $T C(P<0,05)$. Estes resultados podem estar relacionados com as interações entre o PEG e outros compostos fenólicos.

Zerbini et al. (2002), estudando partes da planta de diferentes cultivares de sorgo, encontraram correlações negativas entre a produção de gases em 24 e $96 \mathrm{~h}$ e a presença de compostos fenólicos como o ácido $p$-cumárico.

Resultados semelhantes também foram observados por Wood et al. (1995) em amostras de folhas de árvore. Algumas folhas não apresentaram TC. Entretanto, mostraram inibições de 5 a $10 \mathrm{ml}$ de gases na presença de PVP (polivinilpirrolidona). Os autores encontraram correlações positivas entre os 
incrementos na produção de gases, na precipitação protéica e nas concentrações de compostos fenólicos totais.

O trabalho de Makkar et al. (1995a) avaliou diferentes espécies taniníferas e mostrou correlações positivas de 0,$74 ; 0,64 ; 0,75$ e 0,98 entre o incremento na produção de gases em $24 \mathrm{~h}$ e os teores de compostos fenólicos totais, taninos totais, taninos condensados e a capacidade de precipitação da proteína (BSA), respectivamente. Estes resultados indicaram a eficiência da utilização do PEG 6000 na avaliação dos efeitos antinutricionais dos taninos.

\subsection{Conclusões}

As características fermentativas da planta de sorgo mostraram o seu elevado valor nutricional. Os cultivares graníferos e de duplo propósito promoveram uma maior fermentação microbiana nas idades de 60, 90 e 120 dias após o plantio.

A técnica do bioensaio apresentou resultados compatíveis com as análises químicas apenas para os grãos, indicando a necessidade de um maior número de ensaios em sistema semi-automático e futuras investigações sobre as possíveis interações entre o PEG e outros compostos fenólicos. 


\section{EFEITO DO TANINO DO SORGO EM DIETAS COM ALTA PROPORÇÃO DE CONCENTRADO PARA OVINOS}

\section{RESUMO}

Dietas com elevadas proporções de grãos podem ser uma alternativa interessante para a alimentação de ovinos, pois muitas vezes fornecem maiores quantidades de nutrientes com menores custos. O sorgo é um dos cereais com maior potencial para uso em dietas de ruminantes. Uma das características deste cereal é a presença de taninos condensados nos grãos. $\mathrm{O}$ objetivo deste estudo foi avaliar o valor nutritivo de três cultivares de sorgo com diferentes concentrações de taninos condensados em dietas de ovinos. Foram utilizados seis ovinos adultos ( $P V=56 \mathrm{~kg}$ ), com fístulas de rúmen e duodeno, dispostos em dois Quadrados Latinos 3×3. Os animais receberam (3 \% PV) três dietas com $80 \%$ de concentrado e $20 \%$ de feno de coast-cross, formuladas a partir de três cultivares de sorgo ( $\mathrm{C} 0, \mathrm{C} 1$ e $\mathrm{C} 2$ ). $\mathrm{O}$ consumo, a digestibilidade da matéria seca (DMS), a digestibilidade da proteína bruta (DPB) e o balanço de nitrogênio $(B L)$ foram medidos. Além das medidas do $\mathrm{pH}$ e do nitrogênio amoniacal $\left(\mathrm{N}^{\left.-\mathrm{NH}_{3}\right)}\right.$ no rúmen, foram também determinadas as concentrações de nitrogênio microbiano (NM) no duodeno através do isótopo ${ }^{15} \mathrm{~N}$. Não foram observadas diferenças no consumo dos animais $(P>0,05)$. As dietas $C 0, C 1$ e C2 apresentaram valores de 788, 722 e $747(E P=20,6)$ g. $\mathrm{kg}^{-1}$ para DMS e 633, 535 e $530(E P=35,8) \mathrm{g} / \mathrm{kg}$ para DPB, respectivamente, sendo que a dieta C0 apresentou um valor superior $(P<0,05)$ em relação às demais. $O$ balanço de nitrogênio foi de 14, 10 e $9(E P=1,3) \%$ para $C 0, C 1$ e $C 2$ respectivamente, com 
maior retenção de nitrogênio pela $C 0(P<0,05)$. A concentração de $N M$ no duodeno para $\mathrm{C} 0, \mathrm{C} 1$ e C2 foram de 13,15 e 22 (EP=3,6) g dia ${ }^{-1}$ respectivamente, não havendo diferenças $(P>0,05)$ entre as dietas. Os valores de $\mathrm{pH}$ e N-NH $\mathrm{N}_{3}$ refletiram a dieta com alta proporção de concentrado e não apresentando diferenças $(P>0,05)$ entre os tratamentos. A presença dos taninos condensados no sorgo interferiu na retenção de nitrogênio dos ovinos. Entretanto, não foi notada a inibição do fornecimento de proteína microbiana para o duodeno dos animais.

\section{EFFECT OF TANNINIFEROUS SORGHUM IN SHEEP FED HIGH CONCENTRATE DIETS}

\section{SUMMARY}

High grain diets are an interesting alternative for sheep because may provide more nutrients associated with a low costs. Sorghum is an important grain as ruminant feed but it has condensed tannins in their grains. The aim of this study was to evaluate the nutritive values of three sorghum cultivars with different tannins content in sheep diets. Six male sheep ( $L W=56 \mathrm{~kg})$ with rumen and duodenal cannulaes were allocated in double $3 \times 3$ Latin Square design. Sheep were fed $(3 \% \mathrm{LW})$ with three experimental diets containing $80 \%$ of concentrate and $20 \%$ of coast-cross hay. Diets were formulated with three sorghum cultivars: $\mathrm{C} 0, \mathrm{C} 1$ and $\mathrm{C} 3$. Voluntary intake, dry matter digestibility (DMD), crude protein digestibility (CPD) and nitrogen balance (NB) were measured. Ammonia nitrogen $\left(\mathrm{N}-\mathrm{NH}_{3}\right)$ and $\mathrm{pH}$ were determined in rumen liquor and microbial nitrogen supplies to duodenum (Nmic) were measured trough ${ }^{15} \mathrm{~N}$ trace technique. There were not differences $(P>0,05)$ in voluntary intake. Diets C0, C1 and C2 showed values of 788, 722 and 747 (SE=20.6) $\mathrm{g} / \mathrm{kg}$ for DMD and 633, 535 and 530 (SE=35.8) g/kg for CPD; C0 showed a significant difference among diets $(P<0.05)$. Nitrogen balance was 14,10 and $9(\mathrm{SE}=1.3) \%$ for $\mathrm{C} 0$, 
$C 1$ and $C 2$ respectively and. $C 0$ showed the high nitrogen retention $(P<0.05)$. Values obtained for NM were 13, 15 and 22 (SE=3.6) g.day ${ }^{-1}$ for C0, C1 and C2 respectively, and there were not statistical differences $(P>0.05)$. Rumen ammonia nitrogen $\left(\mathrm{N}-\mathrm{NH}_{3}\right)$ and $\mathrm{pH}$ values demonstrated the effects of high concentrated diets and were not different among treatments $(P>0.05)$. Sorghum condensed tannins interfered in sheep nitrogen retention, however microbial protein supply to duodenum of the animals were not affect.

\subsection{Introdução}

O grão de sorgo é um importante recurso energético na alimentação dos ruminantes. Apesar da grande vantagem dos ruminantes ter como base 0 aproveitamento de alimentos fibrosos, maiores inclusões de fontes de amido nas dietas de animais em terminação implicam em um maior acúmulo de gordura na carcaça e, conseqüentemente, melhor qualidade da carne.

Dietas com elevadas proporções de concentrados podem ser indicadas para alguns sistemas de produção pois, além de apresentarem as maiores concentrações de nutrientes (Sobrinho, 1998),,em muitos casos são também as de menor custo (Susin, 2001).

Elevadas concentrações de grãos nas dietas de ruminantes podem resultar em efeitos negativos na fermentação microbiana (Mould, 1988). A grande disponibilidade de carboidratos fermentecíveis e o rápido crescimento microbiano resultam em baixos valores de $\mathrm{pH}$ do rúmen, inibindo o crescimento dos microrganismos celulolíticos.

Animais alimentados com dietas baseadas em grãos apresentam certa instabilidade na população microbiana. As variações na produção de AGV, a diminuição do poder tamponante do rúmen devido a menor mastigação e a produção de maiores níveis de propionato e butirato pelas bactérias que 
metabolizam ácido lático, são considerados os principais motivos desta instabilidade (Hogan \& Flinn, 1999).

Alguns cultivares de sorgo possuem elevadas concentrações de taninos nos grãos. A presença destas moléculas nas dietas dos animais está relacionada com alguns efeitos negativos, tais como a diminuição do consumo de MS, a diminuição na digestibilidade da proteína, o aumento na perda de proteína endógena e a inibição da atividade microbiana (Makkar et al., 1995a; Ben Salem et al., 1997; McNeill et al., 1998; Godoy et al., 2004). Alguns trabalhos mostram os efeitos positivos dos taninos condensados, tais como a maior absorção de aminoácidos no intestino, a diminuição da perda de nitrogênio via urina e a diminuição de endoparasitas (Aerts et al., 1999; Athanasiadou et al., 2001).

O objetivo deste trabalho foi avaliar dietas formuladas com diferentes cultivares de sorgo contendo diferentes concentrações de taninos na alimentação de ovinos.

\subsection{Material e métodos}

Este experimento foi realizado no Laboratório de Nutrição Animal do Centro de Energia Nuclear na Agricultura (CENA) da Universidade de São Paulo (USP). O experimento foi conduzido em um delinemanto de dois Quadrados Latinos simultâneos com três tratamentos e seis animais (Mead et al. 1999).

\subsubsection{Animais}

Os animais experimentais foram seis ovinos machos adultos e castrados, com predominância da raça Santa Inês. Estes animais possuíam fístulas de rúmen e duodeno e iniciaram o experimento com peso médio de $56 \mathrm{~kg}$. 
Antes do período experimental os animais foram submetidos a exames copro-parasitológicos através da contagem de ovos nas fezes (opg), seguidos de desverminações, até que fossem obtidas contagens menores do que 200 ovos por grama de fezes. Receberam também suplementação com complexo vitamínico ADE.

\subsubsection{Dietas experimentais}

Foram formuladas três dietas experimentais ( $\mathrm{C} 0, \mathrm{C} 1$ e $\mathrm{C} 2)$, com três diferentes cultivares de sorgo e contendo níveis crescentes de taninos condensados (Tabela 4). As dietas experimentais foram formuladas de acordo com as exigências nutricionais e as recomendações do National Research Council (1985) para ovinos. Foi seguida a recomendação para ovinos adultos em terminação (> $50 \mathrm{~kg}$ de peso vivo), utilizando uma relação entre volumoso e concentrado de $20: 80 \%$ MS.

Foram determinadas as concentrações de taninos condensados (TC) nos grãos dos três cultivares escolhidos para comporem os concentrados experimentais. Os cultivares escolhidos foram: C0 (8050 Agromen), C1(SEMEALI - variedade) e C2 (BR700). As concentrações de TC encontradas foram de $0,1,9$ e $2,4 \%$ para os três cultivares respectivamente, que foram analisadas conforme o método do Butanol-HCl descrito por Porter et al. (1986).

Como alimento volumoso foi fornecido um feno de coast-cross (Cynodon dactylon.) com $10 \%$ de proteína bruta (PB). Foi incluído na dieta $2 \%$ de um formulado mineral comercial indicado para ovinos (ovinofós-Tortuga), contendo macro e microminerais.

As dietas experimentais foram fornecidas de maneira restrita, sendo fixadas em $3 \%$ do peso vivo por animal por dia. Foram oferecidas duas vezes ao dia, as 8:30 e às 16:30h. As eventuais sobras foram diariamente recolhidas e pesadas. 
Tabela 4. Composição das dietas experimentais (CO, C1 e C2) formuladas com três cultivares de sorgo com diferentes concentrações de taninos condensados (TC).

\begin{tabular}{lccc}
\hline Ingredientes/Dietas & $C 0\left(\mathrm{~kg}^{-1} \mathrm{MS}\right)$ & $C 1\left(\mathrm{~kg}^{-1} \mathrm{MS}\right)$ & $\mathrm{C2}\left(\mathrm{g} \mathrm{kg}^{-1} \mathrm{MS}\right)$ \\
\hline Feno & 200 & 200 & 200 \\
Sorgo & 730 & 690 & 700 \\
Farelo de soja & 50 & 90 & 80 \\
Mistura mineral & 20 & 20 & 20 \\
\hline$P B(g / \mathrm{kgMS})$ & 120 & 120 & 120 \\
$E M(M J)^{*}$ & 2,57 & 2,58 & 2,58 \\
$T C(\%)$ & 0 & 1,30 & 1,70 \\
\hline
\end{tabular}

* estimada segundo o NRC de ovinos (1985)

\subsubsection{Coletas e preparo das amostras}

Os animais foram mantidos em gaiolas de metabolismo durante 14 dias em cada período. Oito dias foram utilizados para adaptação às dietas e seis para a coleta das sobras, das fezes totais, urina, líquido ruminal (LR) e conteúdo duodenal (CD). Além disto foram feitas infusões ruminais de uma solução marcada $c o m{ }^{15} \mathrm{~N}$, a fim de se estudar a síntese microbiana. Foram também realizadas amostragens de LR para análise do nitrogênio amoniacal $\left(\mathrm{N}-\mathrm{NH}_{3}\right)$ e monitoramento do $\mathrm{pH}$ do rúmen.

\subsubsection{Digestibilidade in vivo e balanço de nitrogênio}

As sobras eram diariamente recolhidas, pesadas e levadas para a estufa $\left(55^{\circ} \mathrm{C}\right.$ por $48 \mathrm{~h}$ ). Após a secagem do material, o mesmo foi moído ( $1 \mathrm{~mm}$ ) evitando separações entre volumoso e concentrado. As amostras foram então analisadas quanto à concentração de matéria seca (MS), matéria orgânica 
(MO), nitrogênio $(\mathrm{N})$, proteína bruta $(\mathrm{PB})$, fibra em detergente neutro (FDN) e fibra em detergente ácido (FDA). As análises de N, PB e FDA foram realizadas seguindo a A.O.A.C. (1990) e a FDN segundo Van Soest et al. (1991).

Todas as fezes foram recolhidas e pesadas. Após a pesagem foram retiradas alíquotas de $10 \%$ do peso total de cada amostra, que foram secas (55 ${ }^{\circ} \mathrm{C}$ por $48 \mathrm{~h}$ ), moídas ( $1 \mathrm{~mm}$ ) e submetidas às mesmas análises realizadas nas sobras.

O total de urina foi recolhido em recipiente próprio com $100 \mathrm{ml}$ de uma solução de ácido sulfúrico $\left(\mathrm{H}_{2} \mathrm{SO}_{4}\right) 10 \%$. O volume total foi medido diariamente e diluído em água até o volume final de 3 litros. Uma alíquota de $20 \mathrm{ml}$ foi recolhida e congelada para posterior análise de nitrogênio.

\subsubsection{Medidas da síntese microbiana}

Para o estudo da síntese de origem microbiana e do fluxo destes microrganismos entre o rúmen e o duodeno foi utilizado o ${ }^{15} \mathrm{~N}$ como marcador. Foi preparada uma solução de sulfato de amônio $\left[\left({ }^{15} \mathrm{NH}_{4}\right)_{2} \mathrm{SO}_{4}\right]$ marcado, com enriquecimento de 90 \%. Esta solução foi diluída em $60 \mathrm{ml}$ de água destilada e aplicada no rúmen dos animais através de uma seringa.

A cada $2 \mathrm{~h}$ foram aplicados $2 \mathrm{ml}$ da solução, sendo que todo o conteúdo das seringas foi aplicado durante $24 \mathrm{~h}$. Os animais receberam a solução durante $72 \mathrm{~h}$ até que o nitrogênio marcado pudesse ser incorporado pelos microrganismos do rúmen e a quantidade de material, entrando e saindo dos compartimentos (rúmen e duodeno), fossem considerados constantes (steadystade). Cada animal recebeu uma dose de $1 \mathrm{mg} \mathrm{de}^{15} \mathrm{~N} \mathrm{~kg}^{-1}$ de peso vivo dia-1, durante os três dias de infusão conforme McAllan et al. (1994).

As coletas do conteúdo duodenal (CD - quilo) foram iniciadas a partir de $36 \mathrm{~h}$ após a primeira aplicação da solução com o sal marcado. Foram coletados , no mínimo, $200 \mathrm{ml}$ de CD nos tempos 0, 4, 8, 12, 16, 20, 24, 28, 32, 36, 40, 
$44,48,52,56,60,64,68$ e $72 \mathrm{~h}$. A cada horário, $20 \mathrm{ml}$ do total coletado foi separado e congelado $\left(-20^{\circ} \mathrm{C}\right)$.

Após o término do experimento as amostras de todos os horários foram homogeneizadas a cada $24 \mathrm{~h}$ resultando em três amostras compostas (pool) representando 24,48 e 72 h após administração do marcador.

Todas as amostras de CD foram liofilizadas, pesadas e analisadas por espectrometria de massa (ANCA-Europa Cientific). Foram então determinados os teores de $\mathrm{N}$ e o $\delta^{15} \mathrm{~N}$ (enriquecimento de ${ }^{15} \mathrm{~N}$ ) das amostras.

Foram também tomadas amostras de LR ao final das $72 \mathrm{~h}$ para a determinação do $\delta^{15} \mathrm{~N}$ dos microrganismos do rúmen. Os microrganismos foram isolados do conteúdo ruminal através de duas centrifugações. Aproximadamente $100 \mathrm{ml}$ de LR foram colhidos de cada animal e centrifugados a $500 \times g$ por 10 minutos. Desta primeira centrifugação foi recolhido apenas o sobrenadante, tendo como objetivo a separação das partículas grosseiras do LR e das bactérias ligadas à fração sólida (SAB). A porção sobrenadante foi então novamente centrifugada a $2000 \times g$ durante 20 minutos. Após a segunda centrifugação o sobrenadante foi descartado, considerando-se que 0 precipitado era constituído de bactérias ligadas a fase líquida ( $L A B)$ e pelas SAB. Os precipitados (pellets) foram então liofilizados, pesados e encaminhados para análise por espectrometria de massas.

$\mathrm{O}$ enriquecimento dos microrganismos do rúmen com ${ }^{15} \mathrm{~N}$ foi calculado através dos valores de $\delta^{15} \mathrm{~N}$ obtido no pellet após $72 \mathrm{~h}$ menos o valor do enriquecimento natural do isótopo $(0,3663 \%)$, fornecido pela Agência Internacional de Energia Atômica (IAEA). Da mesma maneira foi calculado o enriquecimento do $C D$. 
A quantificação do nitrogênio de origem microbiana (NM) contida no CD foi calculada de acordo com os trabalhos de (Brant et al., 1980; McAllan et al., 1992; Pérez et al., 1997), seguindo a seguinte equação:

$$
N M \%=\frac{{ }^{15} \text { Ndigesta }}{{ }^{15} \text { Nbacteria }}
$$

4.2.6. Determinações do pH e nitrogênio amoniacal do rúmen

Para as determinações do $\mathrm{pH}$ e das concentrações de nitrogênio na forma amoniacal no líquido ruminal (LR) foram feitas coletas do LR através de uma sonda diretamente do rúmen dos animais. Foram coletados aproximadamente $60 \mathrm{ml}$ de LR com a sonda. Os horários de coleta foram: 0 , $0,5,1,1,5,2,3,4,5,6,9.5,14$ e 22 horas após a primeira refeição.

$\mathrm{O}$ LR foi imediatamente transferido para um frasco de vidro, o $\mathrm{pH}$ foi medido e uma alíquota de aproximadamente $10 \mathrm{ml}$ foi coletada em tubos de vidro. Nestes tubos, foram adicionadas algumas gotas de $\mathrm{H}_{2} \mathrm{SO}_{4}$ concentrado (18N) para diminuir as perdas de nitrogênio por volatilização. Os tubos foram agitados e congelados. As concentrações de $\mathrm{N}-\mathrm{NH}_{3}$ no $\mathrm{LR}$ foram determinadas em aparelho do tipo micro Kjeldahl seguindo a metodologia descrita por Preston (1995).

\subsubsection{Análise dos dados}

Para a análise estatística foi utilizado o modelo estatístico do delineamento em Quadrado Latino: $\mathbf{Y}_{\mathrm{ijk}}=\boldsymbol{\mu}+\mathbf{t}_{\mathrm{i}}+\mathbf{a}_{\mathrm{j}}+\mathbf{p}_{\mathrm{k}}+\mathbf{e}_{\mathrm{ijk}}$, onde $\mathrm{t}_{\mathrm{i}}$ é o efeito do tratamento i (dietas), $a_{j}$ é o efeito do animal j, $p_{k}$ é o efeito do período $k$ e $e_{i j k}$ o erro associado.

O modelo foi analisado através do programa SAS (2000), através do qual também foram realizadas as comparações entre médias pelo teste de Tukey a $5 \%$ de probabilidade. 


\subsection{Resultados}

Os resultados de consumo, digestibilidade aparente da matéria seca (DMS), da proteína bruta (DPB) e da fibra em detergente neutro (DFDN), assim como o balanço de nitrogênio (BN) e o nitrogênio microbiano (NM) estão apresentados na Tabela 5.

Não foram encontradas diferenças significativas $(P>0,05)$ no consumo de MS dos animais. A DMS apresentou diferença entre os cultivares com alto e baixo tanino $(P<0,05)$ sendo que o maior valor foi de $788 \mathrm{~g} \mathrm{~kg}^{-1}$ obtido com a dieta $C 0$. A DPB foi maior $(P<0,05)$ para a dieta com baixo tanino $(C 0)$, não havendo diferenças significativas entre as dietas C1 e C2. Para a DFDN os maiores valores foram obtidos para $\mathrm{C} 0$ e $\mathrm{C} 2$, sendo que a dieta $\mathrm{C} 1$ apresentou média de $582 \mathrm{~g} \mathrm{~kg}^{-1}$, se diferenciando apenas da dieta $\mathrm{C} 0(\mathrm{P}<0,05)$.

Quanto ao $\mathrm{BN}$ a dieta $\mathrm{C} 0$ apresentou uma maior $(\mathrm{P}<0,05)$ retenção de nitrogênio (14\%) quando comparada com os valores de 9 e $8 \%$ obtidos para C1 e $\mathrm{C} 2$ respectivamente.

O nitrogênio de origem microbiana (NM) foi expresso através do valor total de NM obtido na digesta (gramas por dia), não apresentando diferenças significativas entre os tratamentos $(P>0,05)$.

Foram observadas quedas nos valores de $\mathrm{pH}$ do rúmen após as refeições para os três tratamentos. As menores médias foram obtidas as 3 e 14 h após a primeira refeição.

Os valores de $\mathrm{pH}$ do rúmen mantiveram-se entre 6,0 e 5,6 durante todo o dia. Não foram observadas diferenças significativas entre os tratamentos $(P>0,05)$ sendo que as três dietas apresentaram curvas de $\mathrm{pH}$ semelhantes (Figura 15). 
Tabela 5. Consumo voluntário, digestibilidade da matéria seca (DMS), digestibilidade da proteína bruta $(D P B)$, balanço de nitrogênio $(B N)$ e nitrogênio microbiano (NM) em ovinos deslanados consumindo dietas (CO, C1 e C2) contendo três cultivares de sorgo com diferentes concentrações de taninos condensados.

\begin{tabular}{lcccccc}
\hline Dietas & $\begin{array}{c}\text { Consumo } \\
\left(g \text { dia }^{-1}\right)\end{array}$ & $\begin{array}{c}D M S \\
\left(\mathrm{~g} \mathrm{~kg}^{-1}\right)\end{array}$ & $\begin{array}{c}D P B \\
\left(g \mathrm{~kg}^{-1}\right)\end{array}$ & $\begin{array}{c}D F D N \\
\left(\mathrm{~g} \mathrm{~kg}^{-1}\right)\end{array}$ & $\begin{array}{c}B N \\
(\%)\end{array}$ & $\begin{array}{c}N M \\
\left(g \mathrm{dia}^{-1}\right)\end{array}$ \\
\hline$C 0$ & 1449 & $788^{\mathrm{a}}$ & $633^{\mathrm{a}}$ & $692^{\mathrm{a}}$ & $14,55^{\mathrm{a}}$ & 13,33 \\
$C 1$ & 1430 & $722^{\mathrm{b}}$ & $535^{\mathrm{b}}$ & $582^{\mathrm{b}}$ & $9,48^{\mathrm{b}}$ & 14,88 \\
$C 2$ & 1445 & $747^{\mathrm{b}}$ & $530^{\mathrm{b}}$ & $641^{\mathrm{ab}}$ & $8,38^{\mathrm{b}}$ & 21,67 \\
\hline$P>F^{1}$ & 0,9644 & 0,0325 & 0,0094 & 0,0041 & 0,0051 & 0,1011 \\
$C V^{2}(\%)$ & 9,1 & 4,7 & 10,8 & 6,2 & 20,9 & 37,1 \\
\hline
\end{tabular}

Os valores de nitrogênio amoniacal $\left(\mathrm{N}_{-} \mathrm{NH}_{3}\right)$ obtidos no $\mathrm{LR}$ ficaram entre 4 e $8 \mathrm{mg} \mathrm{L}^{-1}$ para todos os tratamentos, durante as $24 \mathrm{~h}$. Foram observadas diferenças significativas entre os tratamentos apenas $9 \mathrm{~h}$ após a primeira refeição (Figura 16). A dieta C0 apresentou uma concentração de $4,8 \mathrm{mg} \mathrm{L}^{-1}$, sendo considerada mais baixa que as obtidas para C1 e C2 $\left(7,6\right.$ e 6,7 $\mathrm{mg} \mathrm{L}^{-1}$, respectivamente).

\subsection{Discussão}

As dietas não apresentaram diferenças para o consumo de MS, indicando que os cultivares com maiores concentrações de tanino não demonstraram efeito adstringente para os ovinos. Diminuição da palatabilidade das rações devido ao efeito adstringente dos taninos foi descrita por Butler \& 
Rogler (1985). Alguns autores como McNaughton (1987) observaram efeitos negativos no consumo voluntário dos ruminantes a partir de $5 \%$ de TC na dieta.

Trabalhos realizados no Brasil com espécies arbóreas do Nordeste (Silva et al., 1998; Beelen et al., 2003; Godoy et al., 2004) observaram diminuições no consumo voluntário dos ovinos mostrando que o consumo pode estar relacionado não só à concentração de tanino mas também à adaptação dos animais e dos microrganismos do rúmen aos efeitos inibitórios desta molécula.

Os valores obtidos para a digestibilidade aparente da matéria seca (DMS) indicaram um bom aproveitamento das dietas pelos animais. Valores entre 72 e 77 \% para a digestibilidade da matéria orgânica (DMO) foram encontrados por Sherrod \& Furr (1970) em ovinos recebendo $81 \%$ de sorgo de diferentes cultivares na dieta. Defoor et al. (2001), comparando diferentes densidades de plantio e métodos de processamento de grãos de sorgo, obtiveram valores de $74 \%$ para a DMS de ovinos alimentados com $60 \%$ de grãos na dieta.

A dieta C0 apresentou a melhor DMS indicando um possível efeito dos TC presentes nas dietas C1 e C2. Estes efeitos estão relacionados com a maior perda de MS nas fezes devido a sua indisponibilidade para fermentação e digestão. Diminuições na DMS foram descritas em experimentos in situ e in vitro que utilizaram cultivares com alto e baixo tanino no grão (Campos et al. 2002; Cabral et al., 2003, Souza et al. 2003). O estudo de Nsahlai et al. (1998) avaliou a digestibilidade da parte aérea do sorgo entre cultivares resistentes e não-resistentes ao ataque de pássaros e não encontrou diferenças significativas entre os cultivares. 


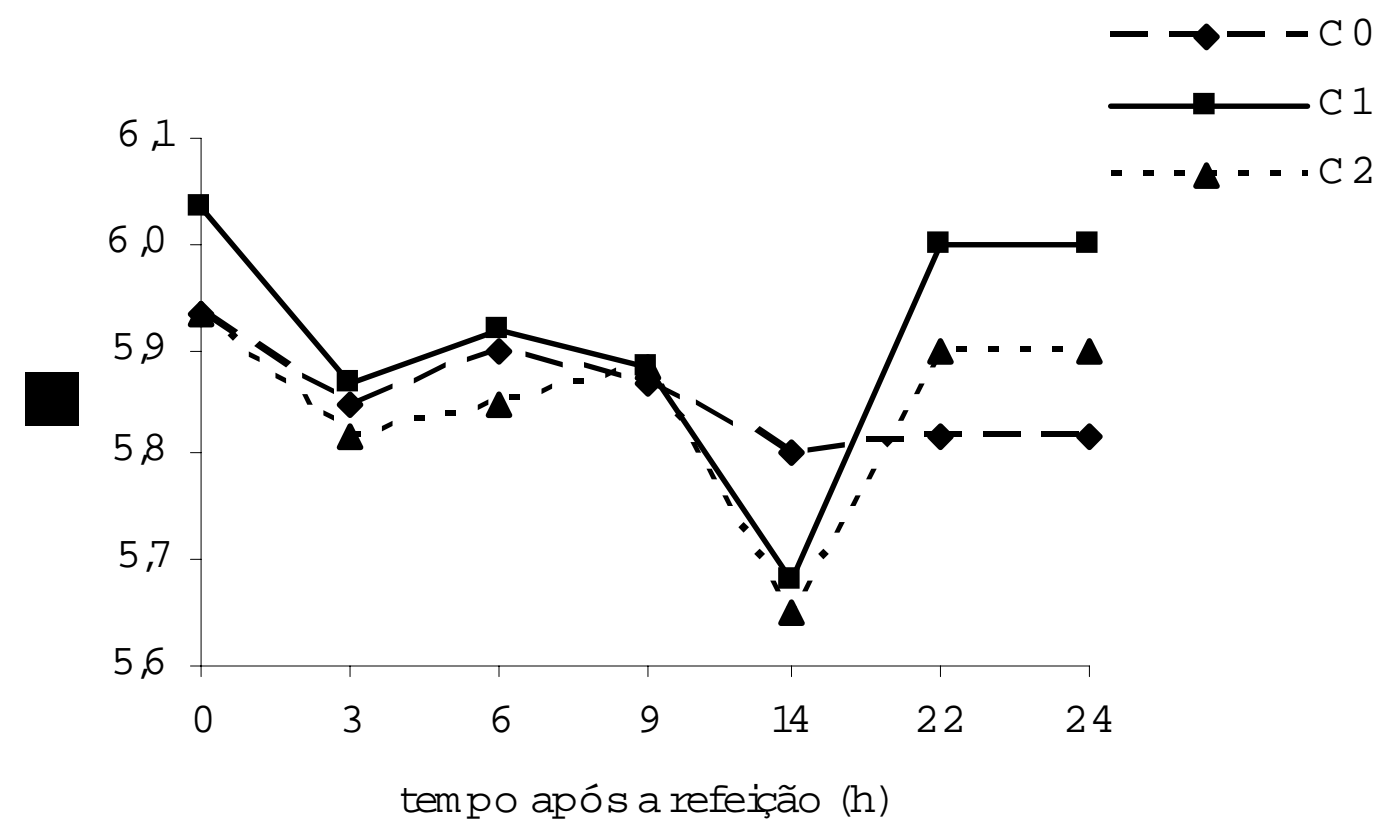

Figura 16 - Variações do $\mathrm{pH}$ ruminal de ovinos alimentados com três cultivares de sorgo, com diferentes concentrações de taninos condensados (CO, C1 e C2). 


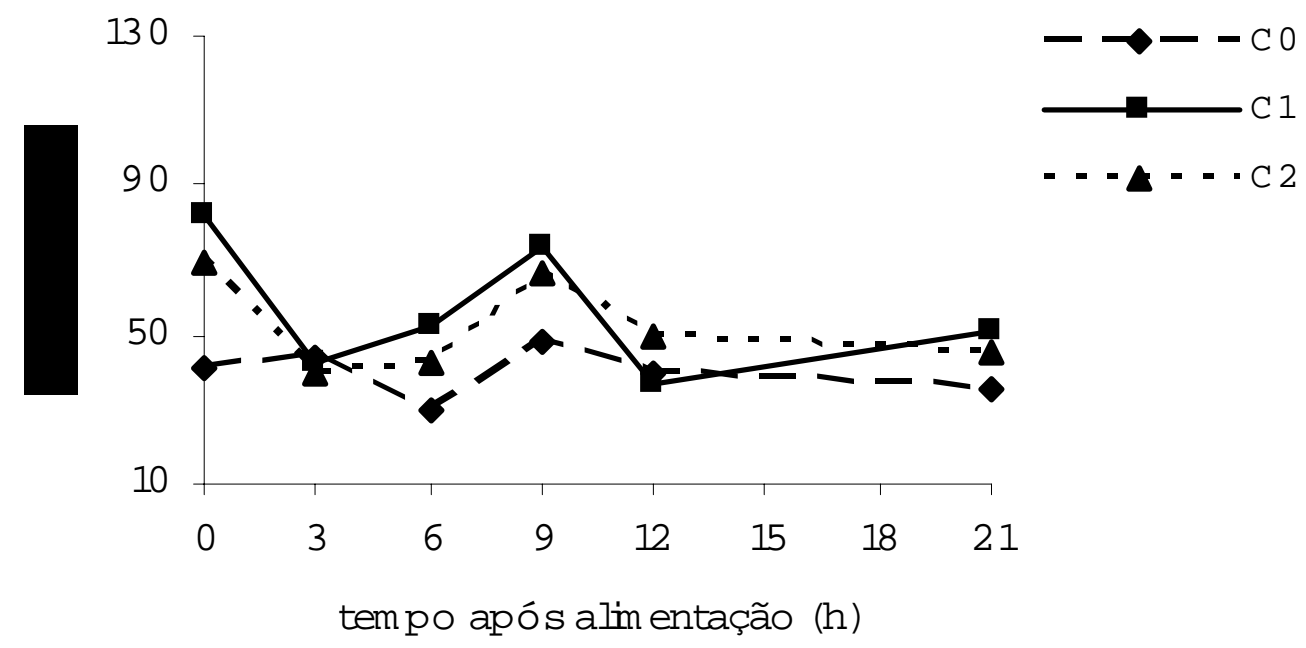

Figura 17 - Variações do $\mathrm{N}-\mathrm{NH}_{3}$ ruminal de ovinos alimentados com três cultivares de sorgo, com diferentes concentrações de taninos condensados (CO, C1 e C2). 
A DPB também apresentou diferenças entre as dietas,com superioridade da C0 em relação a C1 e C2. A diminuição na DPB é característica da ação dos TC na digestão dos animais. Estas moléculas possuem muita afinidade com proteínas, promovendo ligações capazes de indisponibilizar este nutriente para absorção. Butler (1989) associou a redução da digestibilidade da proteína pelos taninos à diminuição da atividade de enzimas ligadas à digestão das proteínas. Possíveis ligações entre os taninos e estas enzimas seriam as responsáveis por esta inatividade. Komolong et al. (2001) trabalhando com níveis crescente de extrato de quebracho (73\% de TC na MS) na dieta de ovinos, notaram uma redução de $10 \%$ na digestibilidade aparente do nitrogênio $\left(R^{2}=0,97\right)$ associado a um incremento de $\mathrm{N}$ das fezes $\left(\mathrm{R}^{2}=0,98\right)$.

Outro estudo realizado por Hervas et al. (2003) com diferentes concentrações de extrato de quebracho, observou um impacto negativo dos taninos condensados no desaparecimento in situ da PB, MS, FDN e FDA a partir da dose de $1,5 \mathrm{~g} \mathrm{~kg}^{-1} \mathrm{PV}$.

A diminuição da digestibilidade da fibra também foi descrita como um efeito antinutricional dos TC (Reed, 2001). O presente estudo observou diminuições significativas da DFDN para a dieta C1. Embora esta dieta tenha apresentado 1,3 \% de TC na MS, não foi observada uma diminuição da DFDN para a dieta $\mathrm{C} 2(1,7 \%$ da $\mathrm{MS})$.

O balanço de nitrogênio indicou uma maior diferença entre as dietas com e sem tanino. A retenção de nitrogênio foi maior para a dieta C0 (14,5\%), mostrando uma maior utilização do nitrogênio pelos animais.

Alguns trabalhos que avaliaram a retenção e o balanço de nitrogênio em ovinos alimentados com forrageiras contendo diferentes concentrações de TC, observaram um aumento das perdas de $\mathrm{N}$ pelas fezes e uma diminuição destas perdas pela urina (Ramirez et al., 1998; Ngwa, 2002; Sliwinski et al., 2002). Estes resultados indicam maiores retenções de nitrogênio para dietas com níveis moderados de TC (1-3\% da MS da dieta). 
Estudos de Nsahlai et al. (1998) encontraram diferenças entre 4,3 e 1,2 g de $\mathrm{N}$ retido por dia em ovinos alimentados com a parte aérea do sorgo com baixo e alto tanino, respectivamente.

Os resultados de Komolong et al. (2001) não demonstraram evidências que sustente a hipótese de que concentrações baixas e moderadas de TC na dieta possam melhorar a utilização do $\mathrm{N}$ pelos ovinos.

Embora os resultados de digestibilidade e do balanço de nitrogênio tenham apontado para uma maior perda de nitrogênio pelos animais que receberam TC na dieta, as determinações do nitrogênio de origem microbiana (NM) no conteúdo duodenal não apresentaram diferenças significativas entre os tratamentos $(P>0,05)$ indicando que os TC não diminuíram a atividade microbiana do rúmen.

Valores de 10, 9, 13 e $13 \mathrm{~g}$ de NM por dia foram encontrados por Komolong, et al. (2001), utilizando 0, 20, 40 e $60 \mathrm{~g} \mathrm{dia}^{-1}$ de extrato de quebracho. Estes valores não apresentaram diferenças significativas $(P<0,10)$,apesar dos autores também terem encontrado diferenças significativas nos valores de digestibilidade do nitrogênio $(P<0,05)$.

Experimentos como os de Pérez et al. (1997) obtiveram valores de 11,9 e $11,5 \mathrm{~g} \mathrm{NM}$ por dia para o LAB e SAB medidos através do ${ }^{15} \mathrm{~N}$ em ovinos recebendo dietas a base de farelo de soja com alta proporção de concentrado.

Outros trabalhos que determinaram as concentrações de NM em ovinos alimentados com $80 \%$ de concentrado de forma restrita e ad libitum obtiveram valores de 14,5 e 17,4 g NM por dia, respectivamente (Carro et al., 2000; Valdés et al., 2000).

Os baixos valores de $\mathrm{pH}$ do rúmen refletiram $\mathrm{O}$ aumento das concentrações de ácido lático devido às elevadas proporções de concentrado na dieta. Reduções no $\mathrm{pH}$ ruminal de ovinos em dietas com elevadas proporções de concentrado foram descritas por Carro et al. (2000). Os autores avaliaram dietas com diferentes proporções de volumoso:concentrado (80:20, $60: 40,40: 60$ e 20:80). Os valores de $\mathrm{pH}$ do rúmen diminuíram de forma linear 
com o aumento dos níveis de concentrado $(6,45 ; 6,40 ; 6,20$ e 5,96; respectivamente).

As elevadas proporções de concentrado e os baixos valores de $\mathrm{pH}$ podem ter sido os responsáveis pelas baixas concentrações de $\mathrm{N}-\mathrm{NH}_{3}$ encontradas no LR. Mudanças na população microbiana do rúmen devido à extensa digestão de amido podem resultar em diminuição da digestão proteica (Hogan \& Flinn, 1999). Estudos de Sultan \& Loerch (1992) mostraram valores máximos de 80 e $200 \mathrm{mg} \mathrm{L}^{-1}$ para ovinos alimentados com 9,5 e $20 \%$ de PB, respectivamente. Enquanto os maiores valores encontrados por Valadarez et al. (1997), em bovinos, foram de 90 e $200 \mathrm{mg} \mathrm{L}^{-1}$, para dietas contendo 7 e $14,5 \%$ de $\mathrm{PB}$, respectivamente.

\subsection{Conclusões}

As dietas formuladas a partir de cultivares de sorgo com maiores concentrações de taninos condensados resultaram em um menor aproveitamento do nitrogênio pelos ovinos. Entretanto, não foram identificadas diminuições do suprimento de nitrogênio microbiano para a absorção intestinal dos animais.

O estudo não identificou a ação antimicrobiana dos taninos condensados do sorgo no rúmen e não confirmou a hipótese de uma maior retenção de nitrogênio em animais recebendo concentrações menores do que $5 \%$ de taninos condensados na dieta. 


\section{CONSIDERAÇÕES FINAIS}

A planta de sorgo apresentou elevado valor nutricional em todos os cortes estudados sugerindo o seu bom aproveitamento em sistemas de corte e pastejo intensivo.

Os cultivares graníferos e de duplo-propósito proporcionaram um melhor ambiente para o crescimento microbiano e podem ser considerados como os de maior qualidade nutricional para os ruminantes.

A comparação entre cultivares mostrada no segundo capítulo deve ser entendida apenas como um indicativo da capacidade de alguns destes cultivares em promover um maior crescimento microbiano, disponibilizando maiores quantidades de nutrientes para os animais. Outros fatores como melhor adaptação, resistência a doenças, maiores produtividades, etc. são utilizados na formação de um material genético e devem ser levados em consideração na escolha do cultivar mais apropriado.

O bioensaio é uma técnica simples e foi capaz de gerar informações qualitativas sobre o efeito dos taninos condensados do sorgo no crescimento microbiano. Entretanto, os resultados obtidos neste estudo não foram suficientes para explicar as variações encontradas nos substratos que apresentaram baixos teores de taninos condensados, questionando a eficiência da técnica em amostras com baixas concentrações de taninos e sugerindo futuros estudos sobre possíveis interações entre o polietileno glicol e outros compostos fenólicos.

Dietas com elevadas proporções de grãos de sorgo apresentaram alta digestibilidade para ovinos, entretanto, a presença de taninos condensados em 
certos cultivares pode influenciar negativamente a utilização do nitrogênio dietético pelos animais. 


\section{REFERÊNCIAS}

AERTS, R.J.; BARRY, T.N.; McNABB, W.C. Polyphenols and Agriculture: beneficial effects of proanthocyanidins in forages. Agriculture Ecosystem and Environment. v.75, p.1-12, 1999.

ASSOCIATION OF OFFICIAL ANALYTICAL CHEMISTY - AOAC. Official methods of analysis. 15.ed. Washington; AOAC, 1990. 1141p.

ATHANASIADOU, S.; KYRIAZAKIS, I.; JAKSON, S.; COOP, R.L. Direct anthelmintic of condensed tannins towards different gastrointestinal nematodes of sheep: in vitro and in vivo studies. Veterinary Parasitology, v.99, p.205-219, 2001.

BEELEN, P.M.G.; BERCHIELLI, T.T.; OLIVEIRA, S.G.; MEDEIROS, A.N.; ARAÚJO FILHO, J.A.; BEELEN, R.N.; FILHO, J.M.P. Influência dos taninos condensados sobre a degradabilidade ruminal da Jurema Preta (Mimosa hostilis), Sabiá (Mimosa caesalpinifolia) e Mororó (Bauhinia cheilantha). (Compact disc). In: REUNIÃO ANUAL DA SOCIEDADE BRASILEIRA DE ZOOTECNIA, 40., Santa Maria, 2003. Anais. Santa Maria: SBZ, 2003.

BEN SALEM, H.; NEFZAOUI, A.; BEN SALEM, L.; TISSERAND, J.L. Effects of Acacia cyanophylla Lindl. foliage supply on intake and digestion by sheep fed lucerne hay-based diets. Animal Feed Science and Technology, v.68, p.101-113, 1997. 
BHAT, T.K.; SINGH, B.; SHARMA, O.P. Microbial degradation of tannins: A current perspective. Biodegradation, v.9, p.343-357, 1998.

BRADFORD, K.J.; HSIAO, T.C. Physiological responses to moderate water stress. In: LANGE, O.L.; NOBEL, P.S.; OSMOND, C.B.; ZIEGLER, E.H. (Ed.) Physiological plant ecology. II. Water relations and carbon assimilation. Berlin: Springer Verlag, 1982. p.253-262.

BRANDT, M.; ROHR, K.; LEBZEIN, P. Determination of microbial protein synthesized in the rumen by means of ${ }^{15} \mathrm{~N}$. In: OSLAGE, H.J.; ROHR, K. Protein metabolism and nutrition. London: Butterworth, 1980. p.496-503. (EAAP Publication, 23).

BUENO, I.C.S.; ABDALLA, A.L.; CABRAL FILHO, S.L.S.; VITTI, D.M.S.S.; OWEN, E.; MAURICIO, R.M.; GIVENS, I.; SUTTON, J.D.; MOULD, F.L. Comparison of inocula from sheep and cattle for the in vitro gas production under tropical conditions. In: ANNUAL MEETING OF THE BRITISH SOCIETY OF ANIMAL SCIENCE, Scarborough, 1999. Proceedings. Penicuik:: BSAS, 1999b. p.151.

BULLARD, R.W.; YORK. J.D. Screening grain sorghum for bird tolerance and nutritional quality. Crop Protection, v.15, n.2, p.159-165, 1996.

BUTLER, L.G. Effects of condensed tannins on animal nutrition. In: HEMINGWAY, R.W.; KERCHESY, J.J. (Ed.) Chemistry and significance of condensed tannins. New York: Plenum Press, 1989. p.391-402.

BUTLER, L.G.; ROGLER, J. Enhancement of high tannins sorghum utilization: characterization, metabolism and detoxification of sorghum tannins and other 
polyphenols. In: WINN, J.F. (Ed.) Intsormil fighting hunger with research. Lincoln: University of Nebraska, 1985. p.140-145.

BUTLER, L.G.; PRINCE, M.L.; BOTHERTON, J.E. Vanillin assay for proanthocyanidins (condensed tannins): modification of the solvent for estimation of degree of polymerization. Journal of Agriculture Food and Chemistry, v.30, p.1087-1089, 1982.

CABRAL, L.S.; VALADARES FILHO, S.C.; DETMANN, E.; ZERVOUDAKIS, T.; PEREIRA, O.G.; VELOSO R.G. Composição quimico-bromatológica, produção de gás, digestibilidade in vitro da matéria seca e NDT estimado da silagem de sorgo com diferentes proporções de panículas. Revista Brasileira de Zootecnia, v.32, p.1250-1258, 2003.

CAMPOS, F.P.; LANNA, D.P.D.; BOSE, M.L.V.; BOIN, C.; SARMENTO, P. Degradabilidade do capim-elefante em diferentes estágios de maturidade avaliada pelo método in vitro/gás. Scientia Agricola, v.59, n.2, p.217-225, 2002.

CAMPOS, W.E.; SATURNINO, H.M.; SOUSA, B.M.; BORGES, I.; GONÇALVES, L.C.; FERREIRA, P.M.; CARVALHO, A.U. Degradabilidade in situ da silagem de quatro genótipos de sorgo com e sem tanino. I. Matéria seca e proteína bruta. Arquivo Brasileiro de Medicina Veterinária e Zootecnia, v.55, n.2, p.209-215, 2003.

CANNAS, A. Tannins: fascinating but sometimes dangerous molecules. Itaka, 1999. http://www.ansci.cornell.edu/plants/toxicagents/tannin.htm (30 mar. 99). 
CARRO, M.D.; VALDÉS, C.; RANILLA, M.J.; GONZÁLES, J.S. Effects of forage to concentrate ration in the diet on ruminal fermentation and digesta flow kinetics in sheep offered food at a fixed and restricted level of intake. Animal Science, v.70, p.127-134, 2000.

DEFOOR, P.J.; COLE, N.A.; GALYEAN, M.L.; JONES, O.R. Effects of grain sorghum planting density and processing method on nutrient digestibility and retention by ruminants. Journal of Animal Science, v.79, p.19-25, 2001.

ELKIN, R.G.; ROGLER, J.C. Differential response of ducks and chicks to dietary sorghum tannins. Journal of Science Food and Agricultural, v.57, p.543-553, 1991.

FRANCE, J.; DHANOA, M.S.; THEODOROU, M.K.; LISTER, S.J.; DAVIES, S.J.; ISAC, D. A model to interpret gas accumulation profiles with in vitro degradation of ruminant feeds. Journal of Theoretical Biology, v.163, p.99-111, 1993.

GERDES, L.; WERNER, J.C.; COLOZZA, M.T.; POSSENTI, R.A.; SCHAMMASS, E.A. Avaliação de características de valor nutritivo das gramíneas forrageiras Marandu, Setária e Tanzânia nas estações do ano. Revista Brasileira de Zootecnia, v.24, n.4, p.955-963, 2000.

GETACHEW, G. Tannins in tropical multipurpose tree species: Localization and quantification of tannins using histochemical and approaches and the effect of tannins on in vitro rumen fermentation. Stuttgart, 1999. 186p. Dissertation (M.S.) - Universität Hohenheim.

GETACHEW, G.; MAKKAR, H.P.; BECKER, K. Effects of polyethylene glycol on in vitro degradability of nitrogen and microbial protein synthesis from 
tannin-rich browse and herbaceous legumes. British Journal of Nutrition, v.84, p.73-83, 2000.

GODOY, P.B.; BUENO, I.C.S.; NOZELLA, E.F.; CABRAL FILHO, S.L.S.; LONGO, C.; SILVA FILHO, J.C.; COSTA, C.; BUENO, M.S.; VIEIRA, E.Q.; MULLER-HARVEY, I.; ABDALLA, A.L.; VITTI, D.M.S.S. Intake and digestibility of tanniniferous browse species fed to sheep in three different levels of protein supply. (Compact disc). In: ANNUAL MEETING OF THE BRITSH SOCIETY OF ANIMAL SCIENCE, York, 2004. Proceedings. Penicuik:: BSAS, 2004.

GOERING, H.K.; VAN SOEST, P.J. Forage fiber analyses (Apparatus, Reagents, Procedures and Some Applications). Washington: ARS-USDA, 1970. 116p. (Agriculture Handbook, 379).

GOMIDE, J.A.; NOLLER, C.H.; MOTT, G.O.; CONRAD, J.H.; HILL, D.L. Mineral composition of six tropical grasses as influenced by plant age and nitrogen fertilization. Agronomy Journal, v.61, p.120-123, 1969.

GONTIJO NETO, M.M.; OBEID, J.A.; PEREIRA, O.G.; CECON, P.R. CÂNDIDO, M.J.D.; MIRANDA, L.F. Híbridos de sorgo (Sorghum bicolor (L.) Moench) cultivados sob níveis crescentes de adubação. Rendimento, proteína bruta e digetibilidade in vitro. Revista Brasileira de Zootecnia, v.31, n.4, p.1640-1647, 2002.

HAHN, D.H.; ROONEY, L.W. Effect of genotype on tannins and phenols of sorghum. Cereal Chemistry, v.63, n.1, p.4-8, 1986.

HASLAM, E. Chemistry of vegetable tannins. London: Academic Press, 1966. 179p. 
HASLAM, E. Vegetable tannins. In: CONN, E.E. (Ed). The biochemistry of plants. London: Academic Press, 1981. p.527-556.

HOGAN, J.P.; FLINN, P.C. An assessment by in vivo methods of grain quality for ruminants. Australian Journal of Agricultural Research, v.50, p.843-854, 1999.

KOMOLONG, M.K.; BARBER, D.G.; McNEILL, D.M. Post-ruminal protein supply and $\mathrm{N}$ retention of weaner sheep fed on a basal diet of lucerne hay (Medicago sativa) with increasing levels quebracho tannins. Animal Feed Science and Technology, v.92, p.59-72, 2001.

LEINMÜLLER, E.; STEINGASS, H.; MENKE K. Tannins in ruminant feedstuff. Animal Research and Development, v.33, p.9-62, 1991.

MAKKAR, H.P.S. Quantification of tannins in tree foliage. Vienna: FAO; IAEA, 2000.

MAKKAR, H.P.S. Chemical protein precipitation and bioassays for tannins, effects and fate of tannins, and strategies to overcome detrimental effects of feeding tannin-rich feeds. In: SEMINAR OF THE FAO-CIHEAM SUBNETWORK ON SHEEP AND GOAT NUTRITION, 9., Hammamet, Tunisia, 2001. Vienna: IAEA, 2001. p.59.

MAKKAR, H.P.S.; BLUMMEL, M.; BECKER, K. Formation of complexes between polyvinyl pyrrolidones or polyethylene glycols and tannins, and their implication in gas production and true digestibility in vitro techniques. British Journal of Nutrition, v.73, p.897-913, 1995. 
MAKKAR, H.P.S.; BLUMMEL, M.; BOROWY, N.K.; BECKER, K. Gravimetric determination of tannins and their correlations with chemical and protein precipitations methods. Journal of Science of Food and Agriculture, v.61, p.161-165, 1993.

MAURICIO, R.M.; MOULD, F.L.; DHANOA, M.S.; OWEN, E.; CHANNA, K.S.; THEODOROU, M.K. A semi-automated in vitro gas production technique for ruminant feedstuff evaluation. Animal Feed Science and Technology, v.79, p.321-330, 1999.

MAURÍCIO, R.M.; PEREIRA, L.G.R.; GONÇALVES, RODRIGUEZ, N.M.; MARTINS, R.G.R.; RODRIGUES, J.A.S. Potencial da técnica in vitro semiautomática de produção de gases para avaliação de silagens de sorgo (Sorghum bicolor (L.) Moench). Revista Brasileira de Zootecnia, v.32, n.4, p.1013-1020, 2003.

McALLAN, A.B.; SUTTON, J.D.; BEEVER, D.E.; NAPPER, D.J. Rumen fermentation characteristics and duodenal nutrient flow in lactating cows receiving two types of grass silage with two levels of concentrate. Animal Feed Science and Technology, v.46, p.277-291, 1994.

McDONALD, P.; EDWARDS, R.A.; GREENHALGH, C.A.; MORGAN, C.A. Animal nutrition. 5.ed. Zaragoza: Acribia, 1995. 576p.

McDOWELL, L.R.; VALLE, G. Major minerals in forages. In: GIVENS, D.I.; OWEN, E.; AXFORD, R.F.E.; OMED, H.M. (Ed.) Forage evaluation in ruminant nutrition. Wallingford: CAB International, 2000. p.373-397. 
McNAUGHTON, S.J. Adaptation of herbivores to seasons changes in nutrient supply. In: HACKER, J.B.; TERNOUTH, J.H. (Ed.) Nutrition of herbivores. Melbourne: Academic Press, 1987. p.391-408.

McNEILL, D.M.; OSBORNE, N.; KOMOLONG, M.K.; NANKERVIS, D. Condense tannins in the Genus Leucena and their nutritional significance for ruminants. In: SHELTON, H.M.; GUTERINDGE, R.C.; MULLEN, B.F.; BRAY, R.A. (Ed.) Leucena - Adaptation, quality and farming system. Canberra: ACIAR, 1998. p.205-214. (ACIAR Proceedings, 86).

McSWEENEY, C.S.; PALMER, B.; McNEILL, D.M.; KRAUSE, D.O. Microbial interaction with tannins: nutritional consequence for ruminants. Animal Feed Science and Technology, v.91, p.83-93, 2001.

MEAD, R.; CURNOW, R.N.; HASTED, A.M. Statistical methods in agriculture and experimental biology. London: Chapman \& Hall, 1993. cap.5, p.59-88: Control of random variation by blocking.

MOULD, F.L. Associative effects of feeds. In: ØRSKOV, E.R. (Ed.) Feed science - World animal science. Amsterdam: Elsevier Science Publish, 1998. p.279-292.

MULLER-HARVEY, I.; McALLAN A.B. Tannins: their biochemistry and nutritional properties. London: JAI Press, 1998. p.151-217. (Advances in Plant Cell Biochemistry and Biotechnology, 1).

NATIONAL RESEARCH COUNCIL. Nutrients requirements of sheep. 6.ed. Washington: National Academic Press, 1985. 99p. 
NGWA, A.T.; NSAHLAI, Y.; IJI, P.A. Effects of supplementing veld hay with a dry meal or silage from pods of Acasia sieberian with or without wheat bran on voluntary intake, digestibility, excretion of purines derivatives, nitrogen utilization, and weight gain in South African Merino sheep. Livestock Production Science, v.77, n.2-3, p.253-264, 2002.

NSAHLAI, L.V.; UMUNNA, N.N.; OSUJI, P.O. Complementarity of bird-resistant and non-bird-resistant varieties of sorghum stover with cottonsed cake and nong (Guizotia abyssinica) cake when fed to sheep. Journal of Agricultural Science, v.130, p.229-239, 1998.

NUSSIO, L.G.; MANZANO, R.P. Silagem de milho. In: SIMPÓSIO SOBRE NUTRIÇÃO DE BOVINOS: ALIMENTAÇÃO SUPLEMENTAR, 7., Piracicaba, 1999. Anais. Piracicaba: FEALQ, 1999. p.27-46.

OKOH, P.N.; OBILANA, A.T.; NJOKU, P.C.; ADUKU. A.O. Proximate analysis, amino acid composition and tannin content of improved Nigerian sorghum varieties and their potential in poultry feeds. Animal Feed Science and Technology, v.7, p.359-364, 1982.

PÉREZ, J.F.; BALCELLS, J.A.; GUADA, J.A.; CASTRILLO, C. Rumen microbial production estimated either from urinary purine derivative excretion or from direct measurements of ${ }^{15} \mathrm{~N}$ and purine bases as microbial markers: effect of protein source and rumen bacteria isolates. Animal Science, v.65, p.225236, 1997.

PORTER, L.J.; HRSTICH, L.N.; CHAN, B.G. The conversion of proanthocyanidins and prodelphinidins to cyanidin and delphinidin. Phytochemistry, v.25, p.223-230, 1986. 
PRESTON, T.R. Biological and chemical analytical methods. In: PRESTON, T.R. Tropical animal feeding: a manual for research workers. Rome: FAO, 1995. cap.9, p.191-264.

RAMIREZ, R.G.; LARA, J.A. Influence of native shurbs Acacia rigidula, Cercidium macrum and Acasia farnesiana on digestibility and nitrogen utilization by sheep. Small Ruminant Research, v.28, n.1, 39-45, 1998.

REED, J.D. Effects of proanthocyanidins on digestion of fiber in forages. Journal of Range Management, v.54, n.4, p.466-473, 2001.

RODRIGUES, N.M.; BORGES, A.L.C.C.; NOGUEIRA, F.S. Silagem de sorgo de porte médio com diferentes teores de tanino e suculência do colmo. IV Influência dos taninos sobre a digestibilidade in vitro da matéria seca. Arquivo Brasileiro de Medicina Veterinária e Zootecnia, v.51, p.577-582, 1999.

RODRIGUES, W.A. Tanino em sorgo: métodos de determinação e análise genética. Piracicaba, 1996. 81p. Tese (Doutorado)-Escola Superior de Agricultura "Luiz de Queiroz", Universidade de São Paulo.

ROSTAGNO, H.S.; FEATHERTSON, W.R.; ROGLER, J.C. Studies on the nutritional values of sorghum grain with varying tannins contents for chicks. 1. Growth studies. Poultry Science, v.52, p.765-72, 1973.

RUSKIN, F.R. Lost crops of Africa: Grains. Washington: National Academic Press, 1996. 386p.

SAS INSTITUTE. The SAS systems for windows. Release 8.01. Cary, 2000. 
SCALBERT, A. Antimicrobial proprieties of tannins. Phytochemistry, v.30, n.12, p.3875-3883, 1991.

SCHOFIELD, P.; MBUGUA, D.M.; PELL, A.N. Analysis of condensed tannins: a review. Animal Feed Science and Technology, v.91, p.21-40, 2001.

SELINGER, L.B.; FOSBERG C.W.; CHENG, K.J. The rumen: a unique source of enzymes for enhancing livestock production. Anaerobe, v.2, p.263-284, 1996.

SHERROD, L.B.; FURR, R.D. Sheep digestibility of rations containing sorghum grains produced with different nitrogen fertilization rates. Journal of Animal Science, v.30, n.6, p.1042-1043, 1970.

SILANIKOVE, N.; PEREVOLOTSKY, A.; PROVENZA, F.D. Use of tanninbinding chemicals to assay for tannins and their negative postingestive effects in ruminants. Animal Feed Science and Technology, v.91, p.69-81, 2001.

SILVA, A.M.A.; PEREIRA FILHO, J.M.; SOUZA, I.S.; VIEIRA, E.L.; AMORIM, O.S. Aceitabilidade por ovinos a espécies lenhosas do semi-árido paraibano. In: REUNIÃO ANUAL DA SOCIEDADE BRASILEIRA DE ZOOTECNIA, 35. Botucatu, 1998. Anais. Botucatu: SBZ, 1998. p.230-232.

SILVA SOBRINHO, A.G. Aspectos quantitativos e qualitativos da produção de carne ovina. In: REUNIÃO ANUAL DA SOCIEDADE BRASILEIRA DE ZOOTECNIA, 38., Piracicaba, 2001. A produção animal na visão dos brasileiros. Piracicaba: FEALQ, 2001. p.425-453. 
SLIWINSKI, B.J.; KREUSER, M.; WETTSTEIN, H.R.; MACHMULLER, A. Rumen fermentation and nitrogen balance of lambs fed diets containing plant extracts rich in tannins and saponins, and associated emission of nitrogen and methane. Archives of Animal Nutrition, v.56, n.6, p.379-392, 2002.

SOUZA, V.G.; PEREIRA, O.G.; MORAES, S.A.; VALADARES FILHO, R.G.S.C.; ZAGO, C.P.; FREITAS, E.V.V. Valor nutritivo da silagem de sorgo. Revista Brasileira de Zootecnia, v.32, n.3, p.753-759, 2003.

STREETER, M.N.; WAGNER, D.G.; HIBBERD, C.A.; OWENS, F.N. Comparation of corn with sorghum grain hybrids: site and extent of digestion in steers. Journal of Animal Science, v.68, n.1, p.1121-1132, 1990.

SULTAN, J.I.; LOERCH, S.C. Effects of protein and energy supplementation of wheat straw-based diets on site of nutrient digestion and nitrogen metabolism of lambs. Journal of Animal Science, v.70, p.2228-2234, 1992.

SULTAN, S.; KATIYAR, D.S.; SINGH, S. Effect of maturity on chemical composition, sugar contents, leaf to stem ratio and in vitro dry matter digestibility of various sorghum cultivars at different stage of maturity. Indian Journal of Animal Science, v.73, n.5, p.541-544, 2003.

SUSIN, I. Confinamentos de cordeiros. In: REUNIÃO ANUAL DA SOCIEDADE BRASILEIRA DE ZOOTECNIA, 38., Piracicaba, 2001. A produção animal na visão dos brasileiros. Piracicaba: FEALQ, 2001. p.454-460.

TEIXEIRA, A.S. Alimentos e alimentação dos animais. 5.ed. Lavras: UFLA, FAEPE, 2001. 241p. 
TILLEY, J.M.A.; TERRY, R.A. A two stage technique for the in vitro digestion of forage crops. Journal of the British Grassland Society, v.18, p.104-108, 1963.

VALADARES, R.F.D.; GONÇALVES, L.C.; SAMPAIO, I.B.; RODRIGUEZ, N.M.; VALADARES FILHO, S.C. Níveis de proteína em dietas de bovinos. 3. pH, amônia e eficiência microbiana. Revista Brasileira de Zootecnia, v.26, n.6, p.1264-1269, 1997.

VALDÉS, C.; CARRO, M.D.; RANILLA, M.J.; GONZÁLES, J.S. Effect of forage to concentrate ration in complete diets offered to sheep on voluntary intake and some digestive parameters. Animal Science, v.70, p.119-126, 2000.

VAN SOEST, P.J.; WINE, R.H. Use of detergent in the analysis of farmers feeds. IV. Determination of plant cell wall constituents. Journal of THE AOAC, v.50, p.50-55, 1967.

VAN SOEST, P.J.; ROBERSON, J.B.; LEWIS, B.A. Method for dietary fiber, neutral detergent fiber, and non-starch polysaccharides in relation to animal nutrition. Journal of Dairy Science, v.74, p.3583-3597, 1991.

WAGHORN, G.C.; SHELTON, I.D.; McNABB, W.C.; McCUTCHEON, S.N. Effects of condensed tannins in Lotus pendiculatus on its nutritive value for sheep 2. Nitrogenous aspects. Journal of Agriculture and Science, v.123, p.109-119, 1994.

WILLIANS, B.A. Cumulative gas-production techniques for forage evaluation. In: GIVENS, D.I.; OWEN, E.; AXFORD, R.F.E.; OMED, H.M. (Ed.) Forage evaluation in ruminant nutrition. Wallingford: CAB International, 2000. p.189-213. 
WOOD, C.D.; PLUMB, V.E. Evaluation of assays for phenolic compounds on the basis of in vitro gas production by rumen micro-organisms. Animal Feed Science and Technology, v.56, p.195-206, 1995.

ZAGO, C.P. Cultura de sorgo para produção de silagem de alto valor nutritivo. In: SIMPÓSIO SOBRE NUTRIÇÃO DE BOVINOS, 4., Piracicaba, 1991. Anais. Piracicaba: FEALQ, 1991. 302p.

ZERBINI, E.; KRISHAN, C.T.; VICTOR, X.V.A.; SHARMA, A. Composition and in vitro gas production of whole stems and cell wall of different genotypes of pearl millet and sorghum. Animal Feed Science and Technology, v.98, p.73-85, 2002. 